Portland State University

PDXScholar

Summer 8-27-2013

\title{
Beyond the Yellow Brick Road: Queer Localization in the Age of Anita Bryant, 1974-1980
}

Stewart John Van Cleve

Portland State University

Follow this and additional works at: https://pdxscholar.library.pdx.edu/open_access_etds

Part of the Gender and Sexuality Commons, Social Influence and Political Communication Commons, and the Social Psychology Commons

Let us know how access to this document benefits you.

\section{Recommended Citation}

Van Cleve, Stewart John, "Beyond the Yellow Brick Road: Queer Localization in the Age of Anita Bryant, 1974-1980" (2013). Dissertations and Theses. Paper 1081.

https://doi.org/10.15760/etd.1081

This Thesis is brought to you for free and open access. It has been accepted for inclusion in Dissertations and Theses by an authorized administrator of PDXScholar. Please contact us if we can make this document more accessible: pdxscholar@pdx.edu. 
Beyond the Yellow Brick Road

Queer Localization in the Age of Anita Bryant, 1974-1980

by

Stewart John Van Cleve

A thesis submitted in partial fulfillment of the requirements for the degree of

Master in Urban Studies

Thesis Committee:

Carl Abbott, Chair

Ann Mussey

Charles Heying

Portland State University

2013 


\begin{abstract}
Collective memories of gay rights in the late 1970s offer a conflicted portrait of Anita Bryant, an infamous anti-gay personality who inspired, organized, or funded four anti-gay referendums between 1976 and 1978. This paper employs J. Jack Halberstam's concept of "metronormativity" in an analysis of campaigns that fought to preserve local gay rights laws in Miami and Eugene, the first and last of Bryant's four "target cities." Using L. Frank Baum's Wizard of $\mathrm{Oz}$ as a metaphor, I compare the beginning of Bryant's role as a leader in Miami to her subsequent role as a specter of national controversy in Eugene. I posit that gay rights leaders in Miami struggled in terms of "queer localization," the ability to localize their ideas, claims, and needs to the voting majority. The loss of gay rights, I argue, led to an inversion of metronormativity in which the outcome of the Eugene referendum affected gay politics in the larger city of Portland, Oregon. I conclude with a comparison of Anita Bryant and San Francisco Supervisor Harvey Milk that suggests both figures created a metronormative myth that can be understood critically in terms of leaving the Yellow Brick Road.
\end{abstract}


Table of Contents

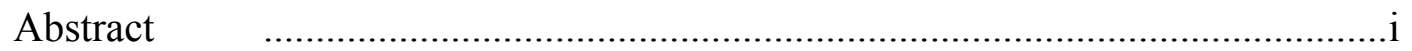

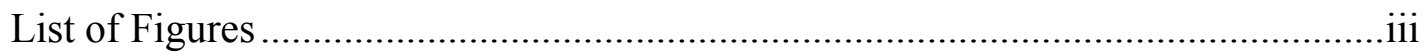

\author{
Chapter 1

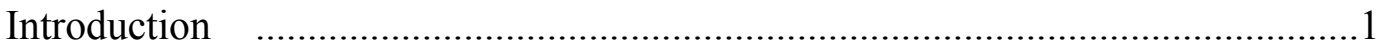

Chapter 2

A Witch in the Storm: The Fight in Dade County, 1976-1977...........................28

Chapter 3

Surrender in the Emerald City: The Loss in Eugene, 1974-1978.........................52

Chapter 4

Conclusion: Memories Behind the Curtain........................................................79

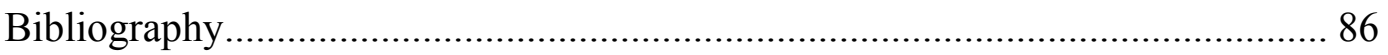




\section{List of Figures}

Figure 1.0: Comparison of Anita Bryant, 1975 and 1977........................................

Figure 1.1: Map of the "target cities" and locations of the Club Bathhouse chain....9

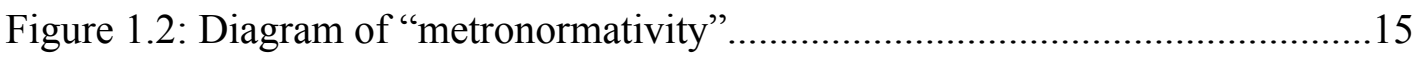

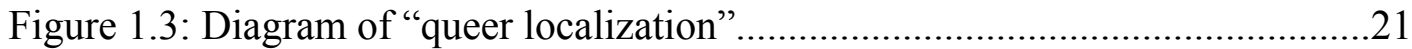

Figure 1.4: Photograph of San Francisco Gay Pride march, 1978_............................24 


\section{Introduction}

"It has long seemed easy to dismiss the decade as a time caught between the militant, heady exuberance of the 1960s and the revival of materialism and the market that defined the 1980s. How to make sense of a period known best by what it was not?" -Kim Phillips-Fein

Bookended by urban riots and the landslide election of Ronald Reagan, the 1970s have become, in the words of Kim Phillips-Fein, "a period known best by what it is not." Its superficial artifacts--disco, feathered hair, pet rocks--suggest a transitory culture without meaning, a waiting period between the radical activism of the past and the rampant consumerism of an impending future. If the first half of the twentieth century imparted narratives of survival, heroics, and the triumphs of American life, the seventies seemingly left a wake of novelties, absences, lies, and failures. ${ }^{1}$ But contradictions between the decade's superficiality and evidence of its depth--Watergate, Network, the fall of Saigon, the Bronx in flames--shape, in the favorite words of the era's activists, a more complex legacy of the seventies as a period of "consciousness-raising." The decade failed to give a cohesive narrative only because it ushered a widespread acknowledgement of paradox in the concept of a monolithic U.S. culture.

Recent films set in the 1970s have reinvigorated the decade's many contradictions. One of those, Gus Van Sant's Milk (2008), offers an early-21st century perspective on how the late 1970s must have looked for the lesbian and gay rights movement in San Francisco. In the film, Harvey Milk faces off against fellow Supervisor Dan White and California State Senator John Briggs, but a third foe receives a different

\footnotetext{
${ }^{1}$ Kim Phillips-Fein, "Decisive Decade: Re-evaluating the Seventies," Dissent, Volume 58, Number 1, Winter 2011, 90.
} 
kind of cinematic attention; an infamous anti-gay crusader, Anita Bryant, only haunts the screen in sporadic newsreels. Despite her comparable absence in the movie, Van Sant used Bryant's appearances to invoke deep memories. When I saw the film at a pre-release screening in Minneapolis, for example, the audience hissed and booed at the very sight of her face, despite her complete absence from the San Francisco storyline. In the lens of the camera, Bryant was both reduced to a newsreel and expanded into a touchstone of national prejudice. Her face became a contradictory memorial to the decade she helped shape.

Milk gives perspective on how lesbian, gay, bisexual and transgender (LGBT) social movements and countercultures exposed one of the seventies' most incongruous memories as a paradoxical kaleidoscope of realities. ${ }^{2}$ The memory of Anita Bryant reveals that the 1970 s can be understood as dialectic of contradictions. In this introduction, I will first give a brief overview of Bryant's role in two voter referendums that rescinded gay nondiscrimination protections in the cities of Miami, Florida in 1977 and Eugene, Oregon in 1978. The two referendums reveal that she played concomitant parts on a national stage; she was a lightning rod of controversy and a key force that recast dominant perceptions of urban queer life in terms of what queer theorist Jack Halberstam identifies as "metronormativity." Throughout the two-year controversy, national media compared Anita Bryant's world to urban communities of vocal, wealthy, and white gay men. Those men ignored lesbians, people of color, and gender nonconformists, and thus encountered problems in terms of what I call "queer localization." As the title and and headings of this paper suggest, I use L Frank Baum's

${ }^{2}$ See: De Groot, Gerard, The Seventies Unplugged: A Kaleidoscopic Look at a Violent Decade (London: MacMillian, 2010). 
The Wizard of $\mathrm{Oz}$ as an analogy to organize the story of Bryant's memory and its relationship to the referendums and the theoretical frameworks I use. Then, as I introduce Chapter 2 and Chapter 3, I focus on the impacts of gay rights losses in Miami and Eugene, and how the memories of those losses, as well as the memory of Anita Bryant, can be better understood in terms of refuting the metronormative memory of gay rights in the late 1970s and rejecting the binaries that those memories support. Finally, I explore the possibilities leaving metronormativity as "the yellow brick road" in order to gain a better perspective on queer localization—understood best, perhaps, in terms of the character Dorothy's revelation about the idiosyncrasies of "home."

In less than two years, Anita Bryant's anti-gay career transformed her from the embodiment of "home" to a specter of national controversy. Before 1977, she achieved small-time celebrity as the 1958 runner-up in the Miss America Pageant, and as a 1960s "Coca-Cola girl" hired by the beverage giant to star in hokey commercials, but most of her celebrity rested in her role on national television. Bryant starred in orange juice commercials in which she typically served breakfast to her children, turned to the camera, held up a glass of juice, and delivered her catchphrase: "A day without orange juice is like a day without sunshine.” But the memory of Anita Bryant as the televised personification of a local Florida mother-seen in the 1975 image to the left, below-pales against a much clearer and more ubiquitous image. She became an infamous antigay personality who, in 1977, initiated a voter referendum that repealed a local gay rights law in Dade County, Florida. 


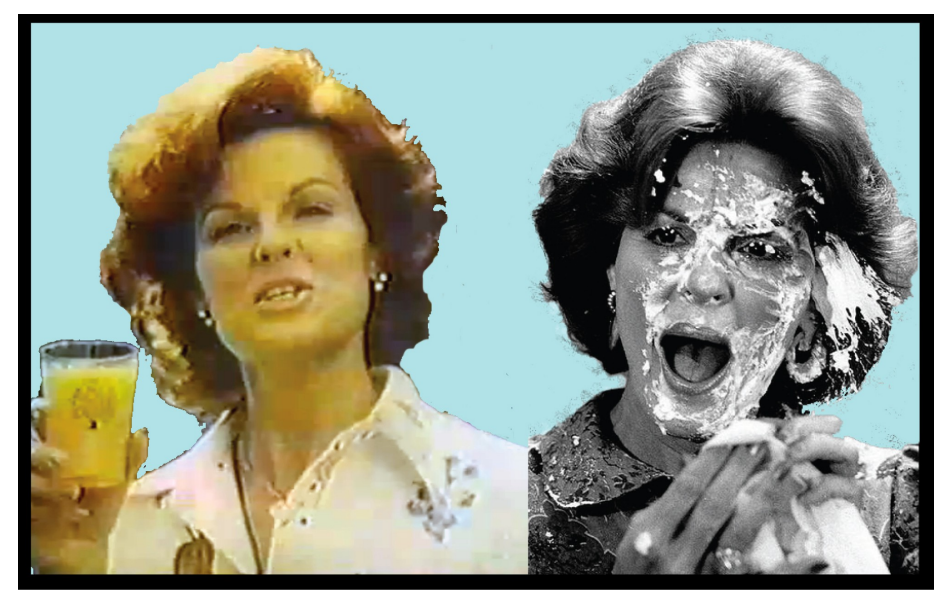

Figure 1.0, left: Anita Bryant in a Florida Orange Growers Commercial (1975); right: Bryant moments after the pie incident, 1977. ${ }^{3}$

The two images above illustrate the two faces of Anita Bryant. In the 1975 commercial, she offered a cheesy portrait of American motherhood; over the next two years, she became a lightning rod of controversy, a symbol of the national media circus, and--to some--she became a "perfect villain" for the gay rights movement to organize against. The photo to the right shows Bryant's face in the context of her national role; the image shows her outrage immediately after a gay activist, Thom Higgins, slammed a banana cream pie into her face during a press conference with national media. As she wiped pie filling from her eyes, she replied "At least it's a fruit pie" and tried to pray for the man who had publicly humiliated her. Her voiced warbled as she spoke the words “deviant lifestyle," and her subsequent sobs, accompanied by clicking cameras and dripping custard, became a manifest symbol of gay retribution.

The large media presence at the pie incident captured a large volume of photographs and newsreels that helped cement Bryant's memory as an unabashed villain. Today, many of those images share space with newspaper clippings, magazine cutouts,

\footnotetext{
${ }^{3}$ Florida Orange Growers Association commercial, air date October 11, 1975 (NBC-TV): http://www.youtube.com/watch?v=4grl5VmSb1Q, created January 26, 2011; retrieved 5/30/2013; Pie photo, Des Moines Register, October 14, 1977.
} 
and correspondence in two archival collections located near two of the cities Bryant's campaign targeted in 1978. The first, the Tretter Collection in GLBT Studies at the University of Minnesota, preserves a slender archival box full of assembled material across the Mississippi River from St. Paul, where, in 1978, voters repealed a gay nondiscrimination ordinance by a 2-to- 1 margin. ${ }^{4}$ The second, located in the Oregon Historical Society in Portland, Oregon, contains two subject files titled "Anita Bryant" approximately 110 miles north of Eugene, Oregon, where voters rescinded gay rights by the same margin a few weeks after the repeal in St. Paul. ${ }^{5}$ In this study, I focus on the Oregon materials, contained in the records of the Portland Town Council (PTC), a collection that I processed as an intern at the Historical Society in the fall and winter of 2011.

Between 1975 and 1982, lesbian and gay activists in Portland, Oregon created the PTC records as office files that contained meeting minutes, newsletters, photographs, membership lists, media clippings, and official publications. The collection also contained a large series of "subject files" of assorted organizations, individuals, and topics outside of Oregon; among these, files labeled "Anti-Gay," "Bryant, Anita," and "Education" contain the primary sources that are relevant to my analysis of the referendums. The PTC's subject files present conflicting understandings of what "community" composed, what that community wanted, and what strategies were required to achieve gay rights. Clearly, the subject files of the PTC represent the attentions of an

\footnotetext{
${ }^{4}$ Anita Bryant Collection, Tretter Collection in GLBT Studies, University of Minnesota Libraries. 5“ Portland Town Council Records, 1974-1982," Coll. 256, Oregon Historical Society Research Library: http://nwda.orbiscascade.org/ark:/80444/xv66189; the Fountain newspaper collection (Portland, OR: The Second Foundation, 1971-1973), vol.1 no.1-vol.3 no.9, sn 89014033, Oregon Historical Society Reading Room :http://librarycatalog.ohs.org/EOSWeb/OPAC/TitleView/CompleteDisplay.aspx? FromOPAC $=$ true $\&$ DbCode $=0 \&$ PatronCode $=0 \&$ Language $=$ english $\&$ RWSearchCode $=0 \&$ WordHits $=\& B i b C$ odes $=4049834$
} 
outsider, especially concerning the fight in Miami-Dade, but they depict an interesting vantage on Anita Bryant and Save Our Children that remains unseen in current scholarship. As I worked in the archive, I paid close attention to the presence of "homonormativity" in the PTC's collection, particularly when it surfaced as a response to the claims of the anti-gay countermovement. As Lisa Duggan notes, homonormativity is an assimilation of heterosexist values among gays and lesbians who do not trouble gender and sexual dichotomies, and who support and sustain them instead. ${ }^{6}$ The narratives contained in the archive suggest that lesbian and gay activists promulgated homonormative ideas in their fight against Anita Bryant and Save Our Children by setting "sophisticated" national forces against their own conception of local provincialism.

The archive highlights Bryant's relationship to the gay rights movement as both an oppressor and as a source of inspiration for gay/lesbian identity transformation. In those lasting roles, she serves as an unwitting historical figure who prompted gay men and lesbians to organize on a national scale. But as the "pieing" of Anita Bryant suggests, she is also shaped by a forgotten memory that casts her as a victimized mother. To some, Bryant remains an ardent Christian warrior who feared for her children's safety, took a stand for her firm beliefs, and encountered a response that, in Bryant's own retrospective words, "seldom in the twentieth century has...one person been subject to."” In the face of death threats, canceled contracts, and encountering chilling evidence of sexist backlash-evident in a popular button that read "Anita Dear--Cram it" or a t-shirt that superimposed her face on the naked body of a woman straddling an orange — she also became a hero.

\footnotetext{
${ }^{6}$ Duggan, Lisa. "The New Homonormativity: The Sexual Politics of Neoliberalism." In Materializing Democracy: Toward a Revitalized Cultural Politics, edited by Russ Castronovo and Dana D. Nelson 175194. Durham, NC: Duke University Press, 2002.

${ }^{7}$ Anita Bryant Ministries, “Anita Bryant Biography,” http://www.anitabmi.org/3.html, retrieved 2/26/2013.
} 
Readers of Good Housekeeping Magazine voted her as "the most admired woman in America" three years in a row and, after all, most voters agreed with her stance on gay nondiscrimination legislation — four vastly different communities each voted to stop it it. ${ }^{8}$

Bryant's rapid transformation from a local mother to the national symbol of antigay sentiment dovetails the history of nondiscrimination protections, as well as the voter referendums that largely reshaped her image. In the late 1970s, sexual nondiscrimination protections became a major point of national contention that brought the concept of "gay rights" to cities that were in varying stages of considering, adopting, or preventing gay rights legislation. Part of a growing national trend, the City Commission of Portland, Oregon passed nondiscrimination protections in 1975 after San Diego, California and two college towns in Michigan passed similar ordinances in 1972. New York City and Washington, D.C. became the second and third large American cities to afford public employment protections in 1973, and St. Paul, Minnesota followed in $1974 .{ }^{9}$ The chain of unopposed victories was short, as a reactive series of grassroots anti-gay organizations greeted the nondiscrimination ordinances in many cities. In 1974, during the nation's first referendum on gay rights legislation, voters in Boulder, $\mathrm{CO}$, repealed a months-old nondiscrimination ordinance and ousted two officials who voted for it. ${ }^{10}$

In 1976, employers, landlords, and establishment owners in Miami-Dade County — like a vast majority of business interests and public agencies across the country—could fire, evict, or deny service to an individual, on the basis of their perceived sexual

\footnotetext{
${ }^{8}$ Good Housekeeping editorial staff. "Results of GH's Eleventh Annual Ten Most Admired Women Poll," Good Housekeeping 190, (1980): 46.

${ }^{9}$ William Eskridge, Gaylaw: Challenging the Apartheid of the Closet (Cambridge, MA: Harvard University Press, 2002), Appendix B, 354-361.

${ }^{10}$ Timothy Phelps, "Gay Issue Splits Colorado Cities." Eugene Register-Guard, October 8, 1995, 8a.
} 
orientation, without fearing legal ramifications for their discrimination. That year, the wealthy owner of a national gay bathhouse chain, Jack Campbell, formed the Dade County Coalition for the Humanistic Rights of Gays—-later the Dade County Coalition for Human Rights - as a lobbying organization that appealed to the Dade County Commission for protections against discrimination. In December of 1976, the Dade County Commission added those protections, and their vote initially received minimal attention from local newspapers. In January 1977, an incensed Anita Bryant launched a campaign called "Save Our Children from Homosexuality"-later "Save Our Children"- to collect signatures that asked the County Commission to hold a special referendum on the issue.

As the name "Save Our Children" implies, anti-gay organizers claimed that nondiscrimination ordinances allowed homosexual teachers to "recruit" impressionable children by advocating the "gay lifestyle." The rhetoric of child protectionism proved extremely effective. By March, Save Our Children had collected 64,000 signatures and, in June, more than 200,000 voters rescinded the gay rights ordinance; Jack Campbell and other gay rights leaders had lost by a two-to-one margin. Bryant's victory inspired her to take Save Our Children on a national campaign to repeal similar nondiscrimination ordinances in other cities. Her announcement had an unintended effect in a city at the opposite corner of the nation. Gay rights organizers in the college town of Eugene, Oregon claimed that Bryant had inspired them to ask the city council for nondiscrimination protections like the ones that Miami had just lost. In November 1977, the Eugene City Council approved the gay rights addendum, and within days of their decision, an anti-gay movement formed to collect signatures in order to put gay rights on 
the ballot. In May 1978, Eugene voters repealed the gay rights ordinance by a two-to-one margin.

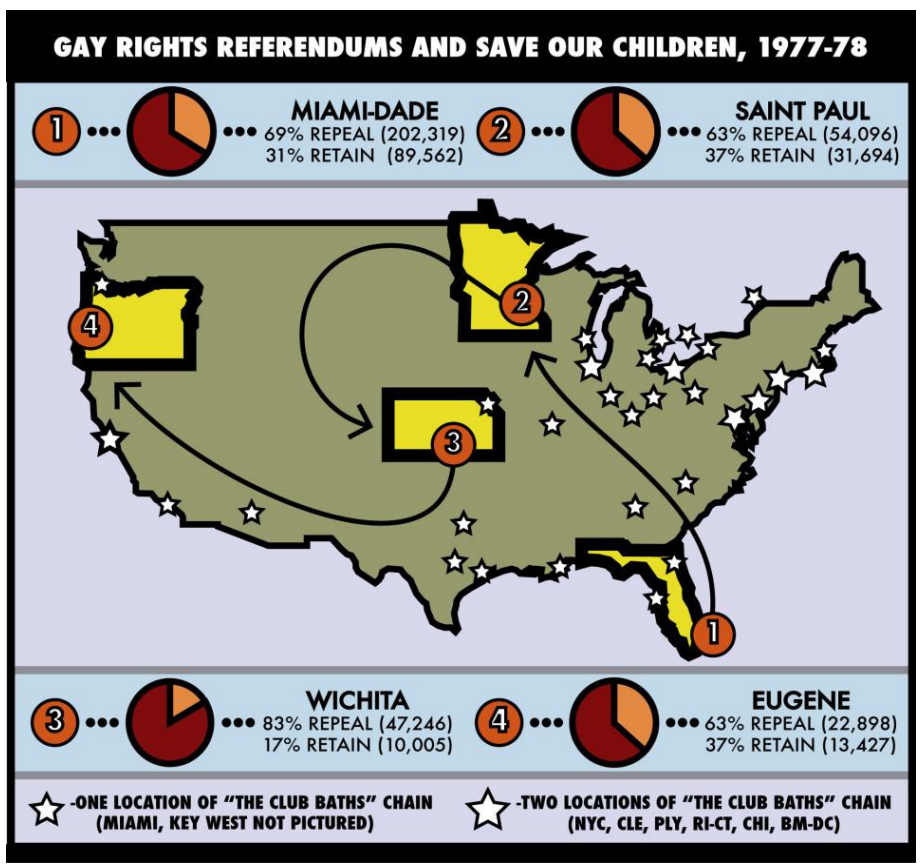

Figure 1.1: Map of the four gay rights referendums and location of Jack Campbell's Club Baths chain, 1977-1978.

The repeal of Eugene's nondiscrimination ordinance was the last of four gay rights losses that spread westward across the nation between June 1977 and June 1978. Though Anita Bryant did not personally organize the referendums in St. Paul, Minnesota, Wichita, Kansas, and Eugene, she continued to hold press conferences--including the famous "pie-incident" conference--and made charged statements about the nature of homosexuality and how she perceived it to be a threat. ${ }^{11}$ The map above shows how the four "Target Cities" represented a westward campaign that meandered from the southeast corner of the nation to the Upper Midwest before it traveled southwest to the Great Plans and culminated in the Pacific Northwest. The map also illustrates a geographical

\footnotetext{
${ }^{11}$ Clendinen, Dudley, and Adam Nagourney. Out for Good: The Struggle to Build a Gay Rights Movement in America. New York, N.Y: Simon \& Schuster, 1999, 322-326.
} 
relationship between the target cities and the locations of Jack Campbell's bathhouse chain. Whereas local voters decided the outcome of the referendums, they became a source of national media attention; while the bathhouses were local chapters, they were part of a broader strive toward forging a national gay male consciousness of sexual liberation and urban sophistication.

Campbell, who led the lobbying effort that brought Miami’s short-lived gay rights ordinance into existence, created a sex-filled urban fantasy world in which men lost themselves and — in the process of patronizing a national chain—became the itinerant migrants of a metropolitan world. He was not a local by any stretch of the imagination. The map depicts how Bryant's campaign broke the "line" of cities where Campbell had established his businesses and brought the battle for gay rights to cities that existed beyond the bathhouse world. Arguably, the four target cities were not folded into Campbell's metropolitan ideal as easily as larger nearby cities-Atlanta, Chicago, Kansas City, Seattle — where bathhouses were more lucrative, nor could they be dismissed as small towns. Instead, they offered a conceptual distance from the supposed loci of queer urbanity, they were populated enough to warrant media interest, and they possessed conceptual associations with southern, Midwestern, Great Plains, and Pacific Northwestern provincialism. Simply put, they were closer to the idea of home that Bryant personified.

The home-like perception of the four target cities may help explain why Bryant, who smiled her way through studio set kitchens and consistently objected to homosexuality "as a mother," was able ground her claims in the domestic sphere as she simultaneously aimed to become a force in national culture. The complexity of Bryant's 
memory as local and national, as villain and hero, and as an embodiment of superficiality and depth folds into broader themes that surround the history of queer life in the late 1970s. These themes can be understood, as the title and headings of this paper suggest, through the familiar lens of The Wizard of $\mathrm{Oz}$, a children's story by Frank L. Baum that has since become a curious touchstone in queer culture. "With Judy Garland as its star," writes Tison Pugh in Innocence, Heterosexuality, and the Queerness of Children's Literature, "its exaggerated characters of good and evil, and its Technicolor wonderland of vibrant colors and outlandish costumes, the film depicts a queer sensibility that countless viewers adore.” He continues:

Although numerous other cinematic classics - from Mildred Pierce to Mommie Dearest - display a queer sensibility that elevates to the status of cultural touchstones in the gay community, The Wizard of $\mathrm{Oz}$ towers above the rest in terms of its iconic role in queer cinema's relationship to queer culture. As Harry M. Benshoff and Sean Griffin observe, 'almost every viewer (queer or not) probably enjoys the film not for its sepia-toned representation of banal 'normality' but for its breathtaking creation of... a land where difference and deviation from the norm are the norm." 12

The Wizard of $\mathrm{Oz}$ offers a parabolic framework for my analysis. In the ubiquitous story, Dorothy finds herself in a magic world after a violent storm takes her from the grey doldrums of rural life. She confronts a wicked witch, meets strange friends, and travels along a winding road to a glimmering city where a wizard is exposed as an ordinary man. The man reveals that Dorothy's friends had what they looked for all along, and Dorothy discovers the film's mantra: that "there's no place like home." All aspects of Anita Bryant and the four target cities can be understood in comparison to that story. In the midst of the 1977 Miami referendum, Twin Cities Pride Committee printed a green-faced Bryant with

\footnotetext{
${ }^{12}$ Tison Pugh, Innocence, Heterosexuality, and the Queerness of Children's Literature (New York: Routledge, 2011), 21.
} 
the caption "And your little dog, too!" on the back cover of its annual guide. Her exaggerated and angry rhetoric fit well into a role as the Wicked Witch, as did her propensity toward terrorizing cities in the manner of writing "Surrender Dorothy" in the skies above the Emerald City. But to some, Bryant was not wicked at all. Her contradictory memory can be understood in the words of another $O z$ quote: when the viewer is introduced to Glinda the Good, she famously asks Dorothy "Are you a good witch, or a bad witch?" We may well ask the same question of Bryant. In the context of Glinda the Good, she can also be understood in terms of how she perceived herself, and how sympathetic others — such as the readers of Good Housekeeping - perceived her; as a red-haired, citrus-hued, and matronly diva who protected young children from evil. If she is no longer perceived this way, as the film Milk suggests, it is only after she carried her view of goodness to the voting public, won their approval, and cemented herself as a short-lived champion of American conservatism.

The memory of Anita Bryant also compares to $O z$ through the major commemorative vehicle of queer history: gay pride parades. As historian David Carter notes in Stonewall: The Riots that Sparked the Gay Revolution, Judy Garland's 1969 funeral began on Manhattan's Upper East Side a few hours before the Stonewall Riots erupted downtown in Greenwich Village. ${ }^{13}$ Occasionally (and, as Carter argues, incorrectly) attributed as the cause of the Stonewall Riots, Garland's death potentially carried a symbolic meaning among younger gay and lesbian activists who saw it as the end of an old gay world. ${ }^{14}$ Garland became further enmeshed into the myths of the new

${ }^{13}$ Lawrence Van Gelder. "Judy Garland's Funeral Draws Her Colleagues,” New York Times, June 28, 1969: http://www.nytimes.com/books/00/04/09/specials/garland-funeral.html.

${ }^{14}$ David Carter, Stonewall: The Riots that Sparked the Gay Revolution (New York: St. Martin's Press, 2004). 
gay rights movement at the 1978 San Francisco gay pride parade, when Gilbert Baker created the rainbow flag, potentially in homage to her famous tune "Somewhere over the Rainbow." ${ }^{\prime 15}$ Attended by tens of thousands as a reaction to Anita Bryant and the loss of gay rights in the four target cities, the rainbow flag's popularity during San Francisco Pride, and its subsequent rise as the symbol of gay rights has further connected a popular narrative of Anita Bryant's role in queer history—evident in Milk—to the story of rainbows told in the Wizard of $\mathrm{Oz}$.

The story offers other points of comparison: Harvey Milk is similar to the wizard, particularly in the film version of his life, and the man behind the curtain in terms of Milk's actual history. As I will detail in the conclusion, his memory as a great and powerful political hero, and as the leader of a San Francisco Ward that drew masses of gay men, is belied by his flippant distaste for old Castro residents who were pushed out of the way to make room for the "gay mecca" he helped create. The terrible storm that leads to an unknown queer world becomes an analogy for Miami-Dade. That city, ironically not threatened by Hurricane Anita in 1977, became a completely-unexpected locus of the national struggle for gay rights. Like Dorothy tumbling around her bedroom during the tornado, Miami voters found themselves wrested from their understandings of a "private matter" by forces beyond their control. After the clouds parted, a strange and dangerous world emerged, and three cities became mismatched companions on a bizarre journey: Wichita, an airplane manufacturing hub on Great Plains; St. Paul, the rusty seat of James J. Hill's former railroad empire; and Eugene, a shy lumber town nestled in the forests of southern Oregon.

\footnotetext{
${ }^{15}$ Les Wright, “San Francisco," Queer Sites: Gay Urban Histories Since 1600, ed. David Higgs (New York: Routledge, 1999), 173.
} 
Finally, connecting them all, the Yellow Brick Road can be understood in terms of "metronormativity," a theoretical framework introduced by Jack Halberstam in 2005. In Halberstam's words, metronormativity "imagines the city as an urban mecca to which rural identified queers must assimilate." 16 It maps the temporal "coming out" process onto a rural-to-urban migration pattern, and expects that all queer people conform to this change. We can further interpret "metronormativity" as conceptualizing "queer space" into a stark dichotomy: the framework views a cohesive "rurality" on the one hand and a uniform "urbanity" on the other. "Metronormativity" thus plays out like the script of The Wizard of $\mathrm{Oz}$, in which Dorothy leaves the farm for the Emerald City. Metronormativity can thus be understood in terms of the process that connects the farm to the city; the yellow brick road is a one-way street. It serves as a temporal and geographic path that connects the province to the great city, a closeted beginning to an "outed" end, and the queer world that existed before Anita Bryant to the one that existed after. Traveling along the narrative's road, various queer constituencies supposedly departed the black-andwhite world of their localities - presented in terms of oppression and internal conflict— and battled Anita Bryant as a Wicked Witch on their way to the promises of Harvey Milk's San Francisco- the queer Emerald City.

While the concept of a metropolitan queer world had enticed national media outlets for more than a decade, Anita Bryant's crusade gave journalists an unprecedented opportunity to explore local gay bars and bathhouses in Miami's upscale "Coconut Grove" neighborhood and compare their findings to the images of piety and fervor that Anita Bryant embodied in her home. Newsweek, the National Observer, and innumerable

${ }^{16}$ Scott Herring, Another Country: Queer Anti-Urbanism (New York: NYU Press, 2012), 14. 
local dailies thus introduce their readers to a specific conception of urban gay life for the first time. Without a large anti-defamation organization--such as the Gay and Lesbian Alliance against Defamation (GLAAD) — yet in existence, journalists published broad statements about homosexuality without fear of reactive or organized censure. The media also offered a number of paradoxes: they cast Bryant as a symbol of stern anti-gay opposition and an object of national ridicule; they depicted the gay world as a wealthy and sex-filled urban fantasy and as a locus of clandestine despair; they framed the four "target cities" as sites of local political struggle as they simultaneously fixated on their significance to national discourse; above all, they promulgated a metronormative understanding of queer life that now pervades it.

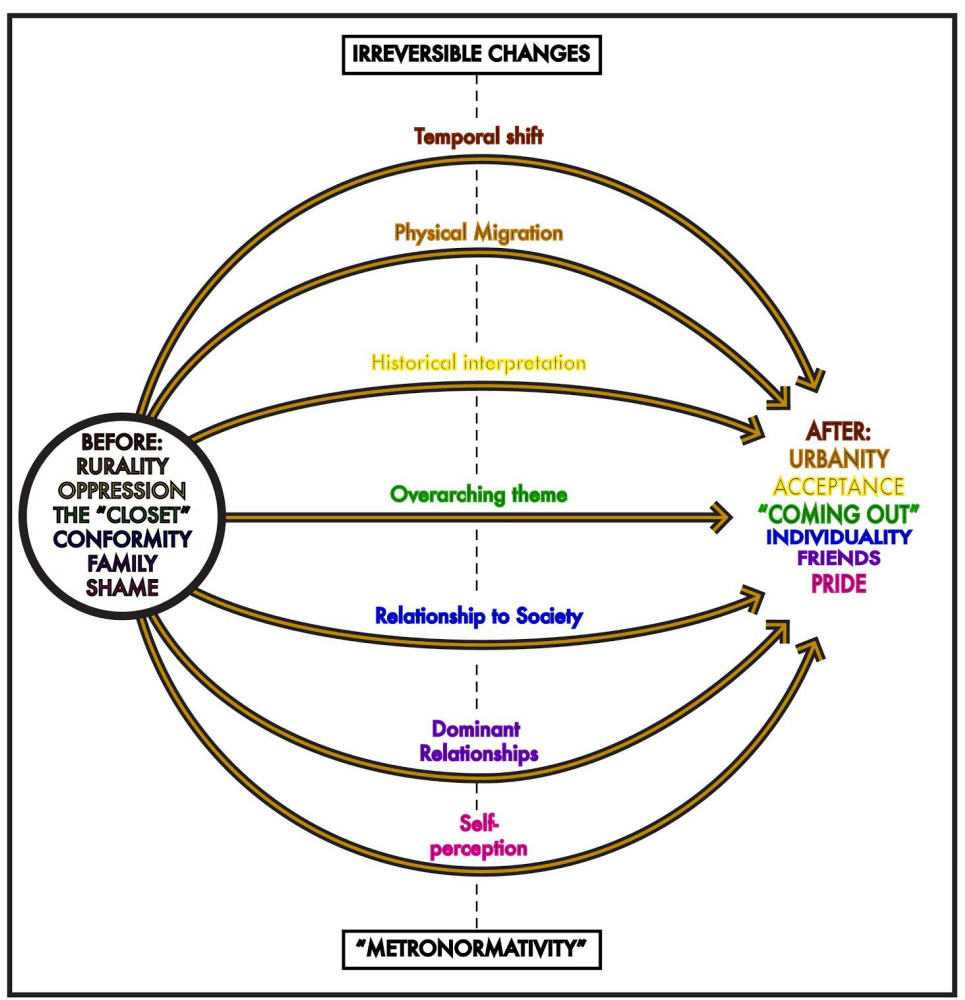

Figure 1.2: Diagram of "metronormativity" 
The diagram above offers a visual interpretation of "metronormativity." The word has dual meanings. It defines a process in which the temporal "coming out" process maps itself onto a path of rural to urban migration, but beyond this definition, metronormativity explains a persistent expectation among those who have undergone that process. To come out as gay, lesbian, bisexual, transgender, or queer, metronormative adherents argue, one must move to a large city. Beyond this definition, metronormativity explains the hegemonic imposition of that metropolitan imaginary onto the lives of rural queers. ${ }^{17} \mathrm{In}$ terms of this paper, I expand metronormativity in order to inspect how gay men and lesbians migrated from the metropolis to "come out" against Bryant in the provincial city of Miami, and how the referendum fight in Eugene affected the politics of Portland, Oregon - the larger and ostensibly more powerful city downriver.

While critics of a Stonewall-centric, "gay pride" commemoration model point to earlier queer riots in an attempt to decentralize New York City as the de-facto historical gay metropolis, other queer theorists point to a pervasive assumption of urbanity that supports queer collective memory, or the nationally-focused queer historical memory, as a whole. Metronormativity casts queer life as decidedly urban and recursively fixes a temporal "coming out" process onto rural-to-urban migration. Metronormativity focuses on a sexual subject who moves from a closeted rurality to a visible urbanity--a process that, in Jack Halberstam's words, "supposedly allows for the full expression of the sexual self in relation to a community of other gays/lesbians/queers." ${ }^{18}$ In other words, metronormativity defines an active queer cosmopolitanism that bolsters large

\footnotetext{
${ }^{17}$ Judith “Jack" Halberstam, In A Queer Time and Place: Transgender Bodies, Subcultural Lives (New York: New York University Press, 2005), 36.

${ }^{18}$ Halberstam, 36.
} 
communities of shared sexual behaviors and gender identities at the expense of a small town, farm, or open countryside. The "urban" is equated with safety and visibility, while the "rural" is equated with danger and hiding.

Jack Halberstam first introduced metronormativity as an alternative framework for understanding the "queer time" and "queer space" that has emerged in the vast "archive" of thought and misinterpretation that surrounds the 1993 death of Brandon Teena, a transgender man who was murdered near Falls City, Nebraska. Halberstam finds that popular novels, documentaries, and films--notably, the award-winning 1999 movie “Boys Don’t Cry"-_depict Teena's life and death in immensely problematic ways that range from misguided and simplistic to transphobic and sexist. In terms of metronormativity, Halberstam's criticizes the journalists, authors and filmmakers who blame Teena's death on his choice to live (what they interpret as) a risky and rural masquerade in a dangerous small town. Halberstam counters this perspective by calling for new queer histories that look beyond the "gay metropolis" and document the complexities and contradictions of living a queer life in unexpected and unsanctioned places. ${ }^{19}$

Since its introduction in 2005, Halberstam's concept of metronormativity has been acknowledged in queer studies of overlooked rural locations across the United States: notably, in Appalachia ${ }^{20}$ and the American South, ${ }^{21}$ by scholars who focused on

\footnotetext{
${ }^{19}$ Halberstam, 22-46.

${ }^{20}$ Detamore, Mathias J., "Queer Appalachia: Toward Geographies of Possibility" (PhD diss., University of Kentucky, 2010), http://uknowledge.uky.edu/gradschool_diss/57.

${ }^{21}$ Scott Herring, "Southern Backwardness: Metronormativity and Regional Visual Culture," American Studies 48, no.2 (Summer 2007): 37-48.
} 
the lesbian "back to the land" communes, ${ }^{22}$ and other instances of queer anti-urbanism. ${ }^{23}$ These studies, I argue, unintentionally support a dichotomy between "rural" and "urban" that has dominated theoretical approaches to understanding queer life in the United States. Indeed, Halberstam's metronormativity frames the geography of Teena's life in those terms, suggesting that his brief residence in Lincoln, Nebraska did not draw him to an urban life as queer expectations would have preferred. Instead, Teena moved to a town of approximately 4,800 residents located near Nebraska's southeast corner, Falls City, in order to live a "rural" life that contained a form of "the beauty and peace in between the brutal realities of poverty, isolation, illness, and violence" that could never be found in the city. ${ }^{24}$ It is important to stress that, for Teena, the distinction between rural and urban was palpable; the distinction was true to him, and on those terms, Halberstam faithfully respected Teena's worldview. But in terms of examining the cultural implications of Teena's death, Halberstam raised the problem of establishing the point where "urban" ends and "rural" begins. If the definition of "rural" has remained constant as the absence of "urban," then the definition of urban has changed dramatically. ${ }^{25}$ Thus, questions remain regarding the nuances of queer urbanity: what differentiates the urbanity of Brandon Teena's Lincoln from, for example, the urbanity of Manhattan on the eve of the Stonewall Riots?

\footnotetext{
${ }^{22}$ Emily A. Kazyak, "The Space and Place of Sexuality: How Rural Lesbians and Gays Narrate Identity," (PhD Diss., University of Michigan, 2010), 9, 70.

${ }^{23}$ Herring, Scott. "Out of the Closets, Into the Woods: RFD, Country Women, and the Post-Stonewall Emergence of Queer Anti-Urbanism." American Quarterly 59, no. 2 (2007): 341-372.

${ }^{24}$ Halberstam, 34.

${ }^{25}$ United States Census, "History: Urban and Rural Areas," retrieved 2/8/2013: http://www.census.gov/history/www/programs/geography/urban_and_rural_areas.html.
} 
Representing an amalgam of queer communities in America's largest cities, namely New York, San Francisco, and Los Angeles, queer urbanity manifested in late 1970s media - especially in The Advocate, Christopher Street, and Gay Community News, and regional newspaper dailies, including The Miami Herald, The Miami News, The Oregonian, and the Eugene Register-Guard - that offered contradictory explanations of what queer life entailed and where it took place. Through those media, murdered San Francisco Supervisor Harvey Milk became a valiant hero, but only after those with mnemonic capacity chose to forget his flippant disregard for longtime Castro residents who were pushed out of the neighborhood. ${ }^{26}$ Similarly, Anita Bryant became a symbol of a one-dimensional hatred only after her popularity among social conservatives and readers of Good Housekeeping were ignored. The mnemonic contradictions inherent in Harvey Milk's commemoration and Anita Bryant's villainy reflect a complex relationship.

Clearly, as Halberstam demonstrates, the nature of metronormativity depends on time and place. To better understand its historical applicability, I take metronormativity out of the context of Brandon Teena and place it in the 1977-1978 referendums in Miami and Eugene. In Chapter 2, I focus on Miami, where local leaders and mass media positioned the cosmopolitan lifestyles of wealthy gay men as "outsiders" against Anita Bryant's "local" Floridian credentials. In terms of the target cities, Metronormativity is most evident in Jack Campbell, the man who organized the gay rights campaign in Miami. Shortly before Miamians voted on the nondiscrimination ordinance, Newsweek

\footnotetext{
${ }^{26}$ Milk's possible sexism can be best understood in the words of his biographer: "Harvey did not have much contact with lesbians, either socially or politically," Randy Shilts, The Mayor of Castro Street: The Life and Times of Harvey Milk (New York: St. Martin's Press, 1988), xiv.
} 
visited Campbell at his mansion in Coconut Grove; he claimed direct lineage to Queen Victoria, he boasted his attendance at Jimmy Carter's inauguration, and--most important of all--he noted that he had only lived in Miami for three years. Jack Campbell thus gave the media--and all of its readers--an impression of gay life as wealthy, well-connected, and capable of uprooting itself to another location. Each of the four target cities, while clearly not "rural," were also not the kind of "urban" that Jack Campbell represented.

Indeed, as I will detail in Chapter 2, Campbell hired professional activists from New York and San Francisco to reshape the Miami Campaign in a metronormative image. The metropolitan experts ostracized local drag queens and other radical nonconformists because their camp politics did not match the expectations of genderconforming people who wanted to enter the workforce; they were a strange "other" whose ludic antics presented rhetorical liabilities to "normal" gay men and lesbians. In accepting the help of national organizations, local gay rights activists positioned the metropolitan arbiters of gay politics against a locally-rooted patchwork of "queer" sexual variation and gender expression that existed within and without the politically-focused and rights-based identity paradigm. Following the definition offered by Annamarie Jagose, queer here relates to "mismatches between sex, gender, and desire;" it "critically analyzes the formation of identity, especially when it reifies social constructions of sexuality and gender. ${ }^{27}$ I argue that a more queer perspective can be applied through the lens of what I call queer localization.

${ }^{27}$ Jagose, Annamarie. "Queer theory." (1996): http://www.australianhumanitiesreview.org/archive/IssueDec-1996/jagose.html, retrieved 2/8/2012. 


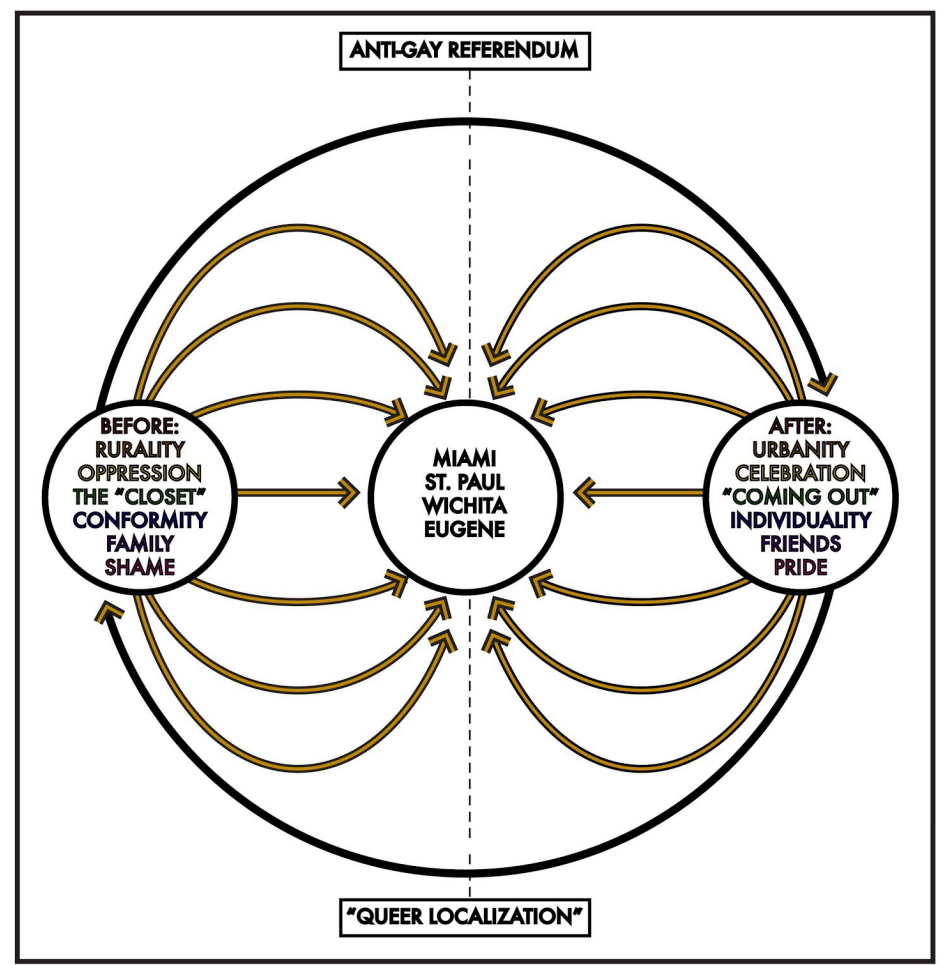

Figure 1.3: Diagram of "queer localization."

Queer localization emphasizes the significance of regional geography, local politics, and local histories as they interact with, accommodate, or ignore a national, LGBT, and rights-based narrative. In the diagram above, I offer a diagram that builds on Figure 1.3 and suggest how "queer localization" builds on metronormativity. Simply put, the four target cities became political and ideological battlegrounds that situated the cities within a complex matrix and within a broader conceptual framework of imagined queer dichotomies. The referendum efforts also brought the notion of gay rights, which the national media had frequently presented as a national issue — or at least an issue that resided in large U.S. cities - to cities that had varying connections to the concept before. Thus, the four target cities became the sites of queer localization as they simultaneously struggle with metronormative interpretations. This contest is rarely identified in queer historiography. Instead, the four cities are often referred to, as if in a roll call, with Anita 
Bryant's career after the repeal of gay rights in Dade County; their unique interactions with the national gay rights movement are relatively unexplored.

The target cities have thus become an amalgamated part of the "national narrative" of queer history. As Marc Stein outlines in an essay on the impact of John D’Emilio's Sexual Politics, Sexual Communities, the field of lesbian, gay, bisexual, and transgender history is dominated by local studies that respond to D'Emilio's "national narrative," which argues that a "community consciousness preceded political activism, which in turn produced new ways of asserting community." ${ }^{28}$ Local histories were difficult to compare, Stein notes, because they focused on different terrains, populations, and periods, such as men in metropolitan New York before WWII; working-class women in Buffalo, New York in mid-century; and anti-urban men in Mississippi from the 1940s to the 1980s. But the national narrative is often imposed in local histories as a reference point, even if its impact was not comparable; indeed, many queer histories have assigned "pre-Stonewall" and "post-Stonewall" temporal frameworks to their studies in order to demarcate the periods that D'Emilio first identified in the early 1980s.

Queer localization has the potential to explore the limits of the national narrative and identify further examples of what Elizabeth A. Armstrong and Suzanna M. Crage call the "Stonewall myth." Armstrong and Crage noted that the 1969 Stonewall Riots in Manhattan became a popular queer origin story because the riots were "the first commemorable event to occur at a time and place where gay activists had enough capacity to produce a commemorative vehicle — that is, where they had adequate

\footnotetext{
${ }^{28}$ Marc Stein, "Theoretical Politics, Local Communities: the Making of U.S. LGBT Historiography," GLQ: A Journal of Lesbian and Gay Studies 11: no. 4 (2005): 605-625.
} 
mnemonic capacity." ${ }^{29}$ The commemorative vehicle, gay pride festivals and parades, have celebrated Stonewall as a principle historical event in most cities and some towns around the world. But queer historians have identified other metropolitan riots, including the 1959 Cooper's Donuts incident in Los Angeles, the 1965 Dewey's Lunch Counter incident in Philadelphia, and the 1966 Compton's Cafeteria riot in San Francisco, that all predate the New York riot and similarly included people of color, gender nonconformists, and prostitutes who defied the police in a seedy urban setting. ${ }^{30}$ In no small part, the Stonewall Inn's location on the doorstep of an alternative newspaper, the Village Voice, uniquely positioned the New York riots for publicity that the other struggles did not receive. "While Stonewall was not the first riot," write Armstrong and Crage, "Stonewall activists were the first to claim to be first;" the mnemonic capacity, then, was a direct result of media attention that not only allowed Stonewall rioters to claim their fight as the first--it allowed many others to hear those claims. ${ }^{32}$

In the 1977-78 referendums, both the gay rights movement and Anita Bryant also made audible claims that had an unprecedented reception. Each side made off-putting claims that simultaneously engaged the nation and alienated local voters, and can be understood in terms of their metronormative assumptions and how that assumption led to subsequent problems in terms of queer localization. Armisted Maupin, a columnist for the San Francisco Chronicle, became the succinct epitome of that problem when he spoke to

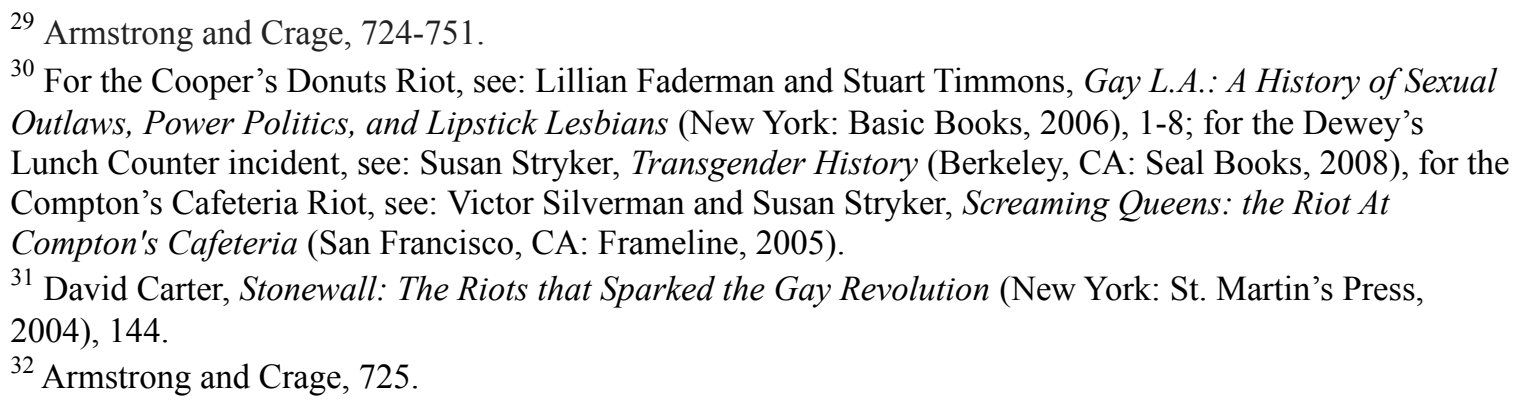

${ }^{30}$ For the Cooper's Donuts Riot, see: Lillian Faderman and Stuart Timmons, Gay L.A.: A History of Sexual Outlaws, Power Politics, and Lipstick Lesbians (New York: Basic Books, 2006), 1-8; for the Dewey's Lunch Counter incident, see: Susan Stryker, Transgender History (Berkeley, CA: Seal Books, 2008), for the Compton's Cafeteria Riot, see: Victor Silverman and Susan Stryker, Screaming Queens: the Riot At Compton's Cafeteria (San Francisco, CA: Frameline, 2005).

${ }^{31}$ David Carter, Stonewall: The Riots that Sparked the Gay Revolution (New York: St. Martin's Press, 2004), 144.

${ }^{32}$ Armstrong and Crage, 725. 
Newsweek about gay resistance to Anita Bryant: “This isn't the kind of campy defiance you had before," he said of San Francisco activists who loaded onto buses and headed for Miami before its 1977 referendum. "These are people with careers they are putting on the line. There was never anything for them to identify with before. Who wanted to get up on a flatbed truck with a bunch of drag queens?"33 If drag queens in trucks were exemplified as du jour queer politics pre-Anita, they were pointedly erased in a post-Anita world of defensive campaigns, unified rhetorical strategies, and media attention.

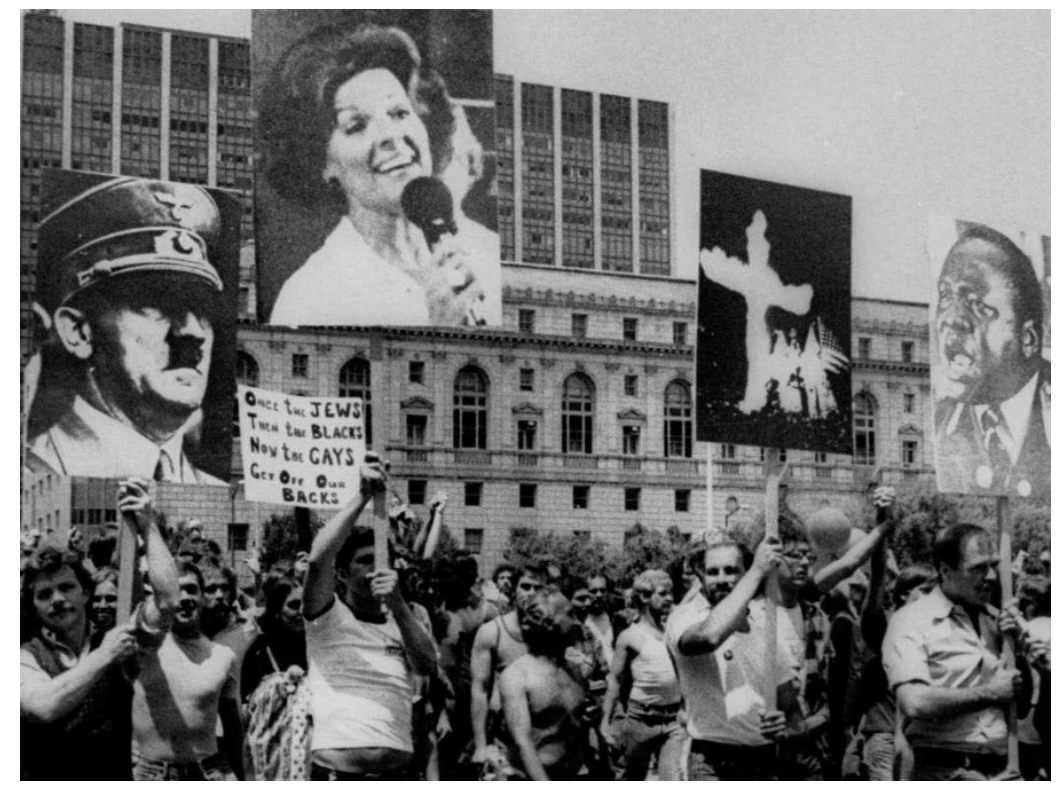

Figure 1.4: San Francisco Gay Pride Parade, San Francisco Chronicle, June 28, 1978.

Figure 1.4 shows the complex interactions that belie the simplicity of the national narrative. In 1978, during the San Francisco gay pride parade, a crowd of white gay men compared Anita Bryant to Idi Amin, Adolph Hitler, and the Ku Klux Klan. The problems associated with the picture are twofold, and they can be understood separately in terms of Miami and in terms of Eugene. In Miami, gay rights leaders ignored the accusations of "child recruitment" that Bryant and Save Our Children Made. Instead, Jack Campbell

\footnotetext{
${ }^{33}$ Tony Fuller and Holly Camp, “Anita Bryant Vs. the Homosexuals,” Newsweek, June 6, 1977, 16.
} 
hired metropolitan professional activists to lead the local gay rights campaign, and those experts compared gay discrimination to the Holocaust and lynching. That comparison is evident in the protest sign pictured above: "One the Jews, then the black, now the gays, get off our backs" While the sign may have worked in San Francisco, other variations of its claim did not go over well. In fact, as I will stress in Chapter 2, Newsweek published an encounter between white gay men and the congregation of a local Baptist church in which one gay man claimed that the struggle for gay rights was the same as the black struggle for civil rights, to which the pastor replied "hogwash." The rhetoric only worked outside of the four cities where it actually mattered.

The problem with the claim was twofold. First, it presented "gays" as inherently distinct from "Jews" and "blacks," thus alienating anyone who identified as gay and black or gay and Jewish. But it also historicized racism and Jewish suffering in the Holocaust, positioned the gay rights movement as "modern," and compared that modernity to the struggles a large black population that experienced racism on a daily basis. Further, gay rights activists claimed comparability to the Holocaust in a city that was home to the largest enclave of holocaust survivors in the United States. These details, along with many others, seemed to be aside the point that gay leaders wanted to make; the actual purpose for the vote—-preserving gay rights, reaching out to voters—often got lost in Coconut Grove, where many gay residents were able to patronize a local country club that banned Jewish or black members.

Second, in terms of the referendum in Eugene, the image betrays a completely different problem that the gay rights movement created: its perceived location. The photo embodied the worst fear of Eugene voters: outsider gay activists, Anita Bryant, and the 
national media would turn the proudly-autonomous city into a firestorm of national controversy. When local gay organizers explained their request for nondiscrimination protections to the Eugene Register-Guard in 1977, they claimed that local anger toward Anita Bryant prompted them into action. The anti-gay movement realized how strongly voters reacted to Bryant, and noted that she would not be invited to the city at the onset of their campaign. In fact, one anti-gay organizer told the paper that they wanted to keep the referendum a "nice, quiet local issue." Keeping with this perspective, local newspapers relegated stories about the Eugene referendum to the backpages, next to the weather report and local advertisements. As I will further explore in Chapter 3, the anxiety of Eugene voters during the referendum can be understood in the context of other fears of "Californication" that pervaded life in the Willamette Valley in the 1960s and 1970s.

The problems that the losses in Miami and Eugene revealed can be understood in terms of queer localization. These struggled, I argue, were evident in three forms: in the rhetoric of "professional" gay activists from New York and San Francisco, who took control over the Miami campaign and shut out the "unsophisticated" perspectives of locals; in the problematic comparisons between the gay rights movement, the Civil Rights Movement, and the Holocaust made by "professional" gay activists; finally, in the fears of a national "militant" gay power among Bryant and the anti-gay countermovement, whose anxieties often fixated on examples from distant or fictitious cities. In the conclusion, I compare the memory of Anita Bryant as a villain with the memory of Harvey Milk as a hero, and, in a comparison of the metronormativity in Miami and the queer localization of Eugene, I expand metronormativity and queer localization into a helpful framework for interpreting the gay rights movement in the late 
1970s. I thus employ a comparative historical analysis of the voter referendums in Miami and Eugene to "achieve the dual goals of theory building and particularistic historical explanation. ${ }^{34}$

This study is an exploration of spaces: the definitive space between urban and rural; the cultural space between Miami and Eugene; the ideological space between gay rights and the anti-gay countermovement; and the theoretical space between metronormativity and queer myth. The spaces reflect a broader mnemonic divide between collective memories of the superficiality and simultaneous depth of the 1970s. Queer localization can be placed in between these spaces, which are best understood by examining their absences, by what they are not. Queer localization focuses on the complexities of urban--that is, not rural--life by examining the dominant metropolitan image of the early gay rights movement. These contradictions--between uniqueness and sameness, the metropolis and the province, and the gay and anti-gay--represented a reciprocity and contradiction that the 1970s embodied.

\footnotetext{
${ }^{34}$ Armstrong, Elizabeth A., and Suzanna M. Crage. "Movements and Memory: The Making of the Stonewall Myth." American Sociological Review 71, no. 5 (2006): 724-751.
} 


\section{Chapter 2: A Witch in the Storm}

The Fight in Dade County, 1976-1977

In November 1976, a recently-elected member of Florida's Dade County Metro Commission, Ruth Shack, announced her sponsorship of an amendment that extended protections against discrimination in housing, public employment, and public accommodation in the County Code. "We do not allow discrimination because of sex or color," she told the Miami News, "and we should not do so because of sexual preference." ${ }^{35}$ Shortly after the announcement, she received an angry telephone call from her friend Anita Bryant, who remembered their conversation in a subsequent interview with the Washington Star. Before reading Leviticus 20:13, a condemnation of homosexuality, over the phone, Bryant told Shack that that she was "embarrassed and sorely disappointed" and warned "I'm going to have to oppose you." Shack, whose ordinance had passed an initial vote without opposition, responded that gay discrimination was a human rights issue, and was thus comparable to the plight of Jews during the Holocaust. ${ }^{36}$ "There are no human rights to corrupt our children," Bryant snapped back, and she abruptly hung up. In her mind, Bryant had made a first foray into political activity of any kind. ${ }^{37}$ Undeterred by her friend's warning, Shack voted with four other colleagues, and the amendment passed on December 7, 1976 with "practically no opposition." 38

\footnotetext{
35 Morton Lucoff, “Homosexual Groups Urging Anti-Bias Law," Miami News, November 16, 1976, 5A.

${ }^{36}$ Frank Rose, "Trouble in Paradise," New Times Magazine, April 15, 1977, 48.

${ }^{37}$ Rosellini, Lynn, “Anita Bryant's Battle With Gays Turns Into a Holy War,” Washington Star (clipping), Portland Town Council Collection, Oregon Historical Society, Collection 256, Box 2, folder 12.

38 Jack Robert, "New Gay Law Causes Flap," Miami News, February 1, 1977, 5A.
} 
A devout Baptist and former second-place contestant in the Miss America pageant, Bryant was a moderately-popular entertainer and the star of television commercials for Coca-Cola, Kraft Foods, and the Florida Citrus Commission, the latter being responsible for her famous catchphrase, "A day without orange juice is like a day without sunshine." With her husband, Bob Green, and four children, she lived in a sixbedroom mansion in upscale Miami Beach. She was also the client of Shack's husband, a booking agent, and she had donated one thousand dollars to Ruth's election campaign in $1976 .{ }^{39}$ In January 1977, with friends, money, and her fame to lose, Bryant sent an open letter to the Metro Commission that criticized Shack's s ordinance: "If this ordinance amendment is allowed to become law," she wrote, "you will in fact be infringing upon my rights or rather discriminating against me as a citizen and a mother to teach my children and set examples and to point to others, as examples, of God's moral code as stated in the holy scriptures." ${ }^{40}$ At the behest of her pastor, Bryant formed "Save Our Children from Homosexuality" (SOC; "From Homosexuality" quickly disappeared), an organization that endeavored to rescind the ordinance through a countywide referendum. ${ }^{41}$

By law, the County Commission could only initiate a referendum after a formal organization acquired ten thousand signatures on a Commission-approved petition. With support from Mayor Steve Clark, Commissioner Robert Blake (who later became the secretary for SOC) sponsored a draft petition for Commission approval. His proposal contained such problematic language that even the county attorney, Stuart Simon, called

\footnotetext{
${ }^{39}$ Morton Lucoff, "Bias Law on Gays Draws Opposition." The Miami News, January 17, 1977, 8a.

${ }^{40}$ United Press International, “Anita Bryant to Protest Gay Rights Ordinance," St. Petersburg Times, January 18, 1977, 12B.

${ }^{41}$ McCreery, 189.
} 
it "propaganda," and Shack took particular umbrage with the petition's wording, which claimed, among other things, that the "purpose of the Metro's ordinance is to allow homosexuals to practice and openly advocate the homosexual's lifestyle...which can be imitated by young people growing up in Dade County." Her only quoted response, "It freaked me out," gave an indication of how extensively her opinions were regarded among her colleagues and the local press. ${ }^{42}$ Instead, the Miami News focused on Stuart Simon, who refused to let the county clerk certify the petition with its problematic language. Blake threatened a lawsuit and, after an emotional public hearing on March 15, the Metropolitan Dade County Commission approved the ballot 6-3. ${ }^{43}$

Throughout March 1977, the Miami News fixated on the impending referendum and its limitless controversy. Reacting one of the paper's many editorials against the ordinance and the referendum--due to its cost--a Miami Beach resident questioned the papers' reference to "flaunting" homosexuals, and asked what that actually meant. "If a person is a known homosexual but conducts himself properly on the job, how is he flaunting? If any person does not conduct himself properly on the job, then the ordinance doesn't protect him." ${ }^{\prime 44}$ Another reader from Miami made a compelling analogy between the expectations of gay nondiscrimination and the realities of straight employment: "Straight people don't think anything about talking about the wife and kids, the house they bought, or their anniversary. Gays should also be able to, unafraid of the consequences." ${ }^{\text {45 }}$ By March 23, the paper carried the headline "Gay Rights: The

\footnotetext{
${ }^{42}$ Morton Lucoff, "Wording Mars Repeal Drive of Law on Gays," Miami News, February 2, 1977, 5A.

${ }^{43}$ Daniel K. Williams, God's Own Party: The Making of the Christian Right (Oxford ; New York : Oxford University Press, 2010), 148; David Holmberg, "Repeal Urged to Kill Election on Gay Rights," Miami News, March 23, 1977, front page.

${ }^{44}$ Neil Rogers, "Human Rights in Conflict," Miami News, March 18, 1977, 13A.

${ }^{45}$ Terry Schoonens, letter to the editor, Miami News, March 18, 1977, 13A.
} 
Emotions, at Least, are in the Open Now," and invited readers to record their opinions on a special telephone hotline--suggesting that editors had received too many letters to handle them in the editorial section alone. "The emotionally charged issue of gay rights has generated rhetoric, charges, counter-charges, petitions, boycotts--and a good deal of confusion," it read." It will probably be that way until June 7." ${ }^{\prime 4}$ On that day, the Commission had determined, voters would go to the polls and vote on the referendum that Anita Bryant had initiated only three months earlier.

\section{Gun-Toting Lesbians and Other Local Problems}

The fight began slowly, in July 1976, when Jack Campbell invited local gay and lesbian groups to his lavish home in Coconut Grove, "Miami’s bleached-out response to Greenwich Village," where he had lived for four years. ${ }^{47}$ Campbell owned the Club Baths, a national chain of more than forty gay bathhouses, and he joined by the Thebans Motorcycle Club, Gay Catholics, the Lesbian Task Force of the National Organization for Women, the Transperience Center, and eight other gay and lesbian activist groups. They formed the "Dade County Coalition for the Human Rights of Gays" (DCC) and distributed two hundred questionnaires to political candidates and publicly supported forty-nine of them. ${ }^{48}$ More than ninety percent of the DCC-supported candidates won, and the group asked one winner, Ruth Shack, to sponsor a nondiscrimination ordinance.

\footnotetext{
${ }^{46}$ David Holmberg, "Gay Rights: The Emotions, At Least, Are in the Open Now," Miami News, March 23, 1977, front page.

${ }^{47}$ Rose, 50.

${ }^{48}$ Rose, Ibid; Grace Lichtenstein, "Life Easier for America's Gays, Despite Anita Bryant Effort," The New York Times, August 21, 1977.
} 
After Anita Bryant created Save Our Children in 1977, the DCC assumed control of the anti-referendum effort and sought help from such gay rights luminaries as Bruce Voeller of the National Gay Task Force, author Gore Vidal, and San Francisco Supervisor Harvey Milk. $^{49}$

The DCC also hired "professional" activist experts from New York City and San Francisco to help the Miami campaign. One of the experts, a New York activist named Ethan Geto, later complained about his experience in an interview with Christopher Street that revealed his incomprehension of the localized circumstances of the campaign..$^{50}$ "I was very disappointed at [the DCC's] low level of political consciousness and their lack of sophistication, organizationally and functionally," Geto remembered. $\mathrm{He}$ joined the fight seven weeks before the special election and immediately elected himself to a largely-unchecked role as "campaign manager." Within four days of his arrival, he aligned himself with the DCC's wealthiest and most powerful member--Jack Campbell-and changed the name of the "Dade County Coalition for the Humanistic Rights of Gays" to the "Dade County Coalition for Human Rights" (DCCHR). Claiming to possess a "unifying factor" and "outsider credibility," Geto silenced those who could not afford a five-dollar membership fee and those who disagreed with him. He even framed the DCC's passage of the ordinance in the context of his expertise: "Remember," he stressed to Christopher Street, "there were some victories before I got there. They got the goddamn ordinance passed." ${ }^{51}$

\footnotetext{
${ }^{49}$ Voeller: Susan Drake with Bill Brubaker "A Cooler Crusader [Anita Bryant], " Newsweek, 90:11, Oct. 3, 1977; Vidal: Statement from Robert S. Basker, coordinator of the Dade County coalition for the Humanistic Rights of Gays, 3/8/1977; Milk: Shilts, 156-167.

${ }^{50}$ Charles Ortleb, "Interview: Ethan Geto: A Seasoned New York Politico," Christopher Street, August 1977, 21-22, 27

${ }^{51}$ Ortleb, 23.
} 
In the interview, Geto recounted a story that cast Miami residents as wild southern provincials and also revealed the latent chauvinism that riddled the Miami referendum. Women were noticeably absent from media observations of the gay rights fight; Newsweek informed readers that "lesbians are generally less visible in Miami and other cities, and they are playing only a modest role in the gay coalition that Campbell has assembled...many lesbians say that male homosexuals are as sexist in their ways as male heterosexuals, making unity difficult." ${ }^{, 52}$ One of the few direct references to queer women related the first meeting Geto attended; he remembered meeting a "paranoid" woman who convinced the committee to purchase a gun for her because she feared being assassinated as a result of her association with gay rights. "When she got angry," Geto recalled, "she pulled out her gun." "I know I'm in the South," he remembered telling her, "but this is a little disconcerting." He then instigated a ban on guns in DCCHR headquarters he thought "sounded like Dodge City in 1845" and effectively barred the woman from participating. ${ }^{53} \mathrm{In}$ framing Miami as both a site of the gun-toting south and as Dodge City, Geto effectively presented the leaders in Miami as equivalent to cowboys in the Wild West; they were outlaws who needed to be civilized.

Even Geto's "professional" rhetoric made critical errors that can be understood as an unwillingness to consider local circumstances. One primary tenet of the DCCHR strategy compared the fight for gay and lesbian rights to the struggles of black civil rights activists in the 1960s or of Jews who suffered in the Holocaust. He and other activist experts retooled the campaign to reflect the perceptions of a "sophisticated" activist ideal;

\footnotetext{
${ }^{52}$ Newsweek, 22.

53 Ortleb, 21.
} 
"Miami is our Selma," said one gay activist to Newsweek. ${ }^{54}$ The strategy often collapsed on an embarrassing scale. "The attempt to link the gay cause with the civil-rights movement of the past seems to leave many Miami blacks a bit cold," wrote Newsweek. "When a group of pro-ordinance people took that line at St. John's Baptist Church last week, the Rev. Thedford Johnson snapped: "Hogwash. When you're black it sticks. You're segregated for the way you look. No one has to know what these people are unless they want it." ${ }^{" 55}$ The Miami News also contested the comparison by noting that homosexuals were not relegated to segregated institutions or subjected to the same "extreme conditions" as black people were prior to the 1964 Civil Rights Act. In fact, the editorial made an especially damning local comparison that completely undermined Geto's claim, noting that many exclusive clubs in the area barred black and Jewish membership but welcomed rich gay men. ${ }^{56}$ Such comparisons were clearly beyond the scope of DCCHR's lofty "human rights" rhetoric.

In comparing their struggle for employment nondiscrimination protections to the Civil Rights Movement, white coalition members cast gayness and blackness as mutually-exclusive forces that separately confronted a two-faced monolith, with whiteness on the one hand and heterosexism on the other. But as the dismissal in St. John's clearly indicated, an intended resonance among black Miamians did not work because the rhetoric understood blackness, racism, and the Civil Rights Movement as abstracts divorced from the people who actually experienced them. Thus, the Rev. Johnson's remark on "the way you look" carried a latent message to gay activists who did

\footnotetext{
${ }^{54}$ Fuller and Camp, 16.

${ }^{55}$ Fuller and Camp, 22.

56 "Vote FOR Repeal of Gay Ordinance," Miami News, June 6, 1977: in McCreery, 194.
} 
not actually want to "see" black people or change their rhetoric to accommodate a more nuanced understanding of political struggle. This botched attempt at outreach can be understood in terms of Jewish voters as well, despite the noticeable absence of Jewish voices in national, local, and gay media accounts. Anita Bryant's own neighborhood, Miami Beach, was home to one of the United States' largest Holocaust survivor communities. ${ }^{57}$ Thus, one can imagine that the survivors were unimpressed by gay men who wantonly appropriated their suffering through unwelcome associations with the Holocaust. The "professional” gay rights movement's associations created oppositional forces--where none needed to exist--in order to employ a rhetorical strategy that had no examples of actual success.

The DCC's rhetoric heralded the initial stages of a shift in how white gay men and lesbians used blackness, in the words of Amy L. Stone and Jane Ward, "as the dominant metaphor for difference, victimization, and resistance" to pursue their own political goals. ${ }^{58}$ Stone and Ward explained that gay and lesbian rights organizations abandoned early 1970 s coalitions with the black civil rights movement; instead, they opted for claims that can be understood as precursors to the twenty-first century claim that "gay is the new black." 59 While Stone and Ward originate the shift to the Miami referendum, the comparison has earlier origins. In 1974, when the Gay Activists Alliance (GAA) tried unsuccessfully to pass a gay civil rights bill in New York City, a group of Manhattan

\footnotetext{
${ }^{57}$ Mark Miller and Matt Propert, National Geographic Traveler: Miami and the Keys (Washington, D.C.: National Geographic 2012), 98.

${ }^{58}$ Stone, Amy L. and Jane Ward. "From 'Black People are not a Homosexual Act' to 'Gay is the New Black:' Mapping White Uses of Blackness in Modern Gay Rights Campaigns in the United States." Social Identities 17 no. 5, (September 2011): 606.

${ }^{59}$ This phrase, as Stone and Ward note, manifested in the 2000s and made manifest a latent attitude among gay and lesbians rights leaders, one that followed gay liberation and preceded a "human rights" strategy that has itself been supplanted by a "color blind" paradigm that focuses on the "acquisition of material benefits." See also McCreery, 188.
} 
activists organized a "Freedom Ride" through the Bronx, Brooklyn, and Queens in search of "non-gay" support in the other boroughs, and possibly established the widespread accommodation of civil rights movement terminology among New York gay and lesbian activists. ${ }^{60}$ At the time, the GAA included in its membership Ethan Geto, who was GAA president's roommate and had already established himself as a formidable gay rights strategist. $^{61}$

\section{"Last Night I Slept with Cleveland” and Other Media Misreporting}

Under Geto's direction, the DCCHR took their cues from the unsucessful nondiscrimination campaign in New York City and applied them to Miami, ignoring the clear political, geographic, and population differences between the two cities. The Christian anti-gay countermovement, embodied by Save Our Children, understood local needs clearly. It originated as a grassroots effort that cast the gay community as an urban antipode to the wholesome and family-oriented local values that Anita Bryant embodied, however paradoxically, in her nationally-televised commercials. Were it not for Bryant's celebrity and the controversial topic of sexuality, a meeting of the Dade County Commission would not have been singled out; heated public meetings abounded in local city halls, and their outcomes rarely made the cover of Newsweek. However, Bryant's crusade brought the legal minutia of municipal politics to the entire nation, and it

\footnotetext{
${ }^{60}$ Christina B. Hanhardt, "Butterflies, Whistles, and Fists: Gay Safe Street Patrols and the New Gay Ghetto, 1976 - 1981," Radical History Review: Queer Futures 100 (Winter 2008): 70.

${ }^{61}$ David Jernigan, "Why Gay Leaders Don't Last: The First Ten Years After Stonewall," Out/Look, Summer 1988, 33-49.
} 
positioned her as both an spokeswomen of local values and a personification of provincial morality that was easily ridiculed on Saturday Night Live. ${ }^{62}$

"Anita Bryant may be a dim memory elsewhere in the country," wrote New Times Magazine, "but in Miami...she has linked herself inextricably with two of Florida's most treasured symbols: sunshine and orange juice. Every Easter there are newspaper articles about the sunrise services she sings at; every New Year's there's coverage of her efforts on behalf of the Orange Bowl. Her records have been sold in supermarkets with bags of oranges; her books get favorable reviews in local papers." ${ }^{63}$ Though born in Oklahoma, Bryant had lived in the Miami area since 1960 and was an embodiment of the ideal Florida woman. ${ }^{64}$ Indeed, as the battle in Dade County intensified, Ruth Shack complained that Bryant's personality had distracted from the issue at hand: "I'm very optimistic that, once we get finished with the issue of Anita Bryant and get on with the issue of human rights," she told the Miami Herald, "people will recognize what this law is and come out and vote for it."

But even Shack, who seemed so confident in her phone call with Bryant months earlier, had backpedaled as a result of Bryant's crusade; in her interview with the Herald, she stressed that she had no intention of showing any further political support for her ordinance ${ }^{65}$ Voters also complained about the overshadowing problem of Anita Bryant's personality: "It seems to me that while the legislation is well-intentioned, there should never have been a need for it," argued a medical doctor, Morris Goldberg, in a letter to

\footnotetext{
${ }^{62}$ Jane Curtin, "Saturday Night Live," September 24, 1977.

${ }^{63}$ Rose, 46.

${ }^{64}$ Stacy Braukman, Communists and Perverts under the Palms: The Johns Committee in Florida (Gainesville, FL: University Press of Florida, 2012), see epilogue.

65 John Arnold, “Metro Must Reconsider Gay Law,” The Miami Herald, March 15, 1977, B1.
} 
the Miami Herald. "There is a Bill of Rights, and enough anti-discrimination legislation to cover almost every action and reaction. There is so much good to be done. Why does Ms. Bryant joust with windmills?" ${ }^{66}$ Still others complained about the referendum's $\$ 400,000$ price tag: arguing for a repeal of the law, the Miami News opined "The special June 7 balloting...will make Dade County into a national battleground between repressive religionists on the one hand and publicity-seeking eccentrics on the other. The community needs neither." ${ }^{67}$ Whether or not the community wanted or needed it, the national fight was already well underway.

Bryant herself predicted that Miami would become a national battleground, where she believed the forces of good were poised to deflect the forces of evil. Distracted by such immense rhetoric, media interests were largely unconcerned with the actual legal ramifications of ordinance if it survived the referendum. An often-misreported claim that the local ordinance would force homosexual teachers in area schools was simply not true, for example, because public schools were managed at the state level. Only private schools were ostensibly under the law's jurisdiction, although the Metro Commission's authority over those schools was dubious at best. ${ }^{68}$ Despite obvious misreporting, the national media had a profoundly negative impact on Dade County. Larry King, then a talk show host on WIOD Miami, noted that the gay rights debate was a divisive topic that seemed inexhaustible. "I've been doing radio for 20 years," he said in an interview with

\footnotetext{
${ }^{66}$ Letter from Morris M. Goldberg, M.D., to the Miami Herald, "Gay Rights Debate Quixotic,” March 15, 1977.

${ }^{67}$ Miami News editorial, "Repeal Gay Ordinance,” March 16, 1977.

68 Tony Fuller and Holly Camp, “Anita Bryant vs. the Homosexuals,” Newsweek, June 6, 1977, 16.
} 
New Times, "and I've never seen the public like it is on this subject. If I did five hours on this every night I'd still have the phones ringing every second. It's polarizing the city." ${ }^{69}$ SOC, which had a clear interest in distracting voters from the limited legal scope of the ordinance, led an intense media campaign that overwhelmed the lesbian and gay community in Miami. Three figures claimed leadership roles in the local gay response to Bryant: Bob Basker, a former homophile activist who began several Miami gay rights organizations in the early 1970s; Bob Kunst, director of "The Miami Victory Campaign" and "The Transperience Center," and Jack Campbell, who headed the "Dade County Coalition for the Humanistic Rights of Gays," and owned The Club Baths. As Patrick McCreery has noted, historians have presented the three men as archetypal indicators of divisions in the gay rights movement: Basker represented the conservative approach of the 1960s homophile movement; Kunst represented gay liberation of the early 1970s; Campbell, the modern representative, was a political pragmatist who simply wanted to make money. ${ }^{70}$

Kunst and Campbell formed competing organizations that revealed a chasm in the gay male community that can be understood through the lens of homonormativity. Kunst firmly believed in a radical form of universal human bisexuality; his Transperience Center included a backroom for three-way sexual enlightenment that gave a transformational sexual experience: in his words, a "transperience."71 Kunst frequently gave headaches to Ethan Geto and other "professional" organizers: in explaining the

\footnotetext{
${ }^{69}$ Rose, 44.

${ }^{70}$ Sears, James T. "Bob Basker (1918-2001): Selling the Movement.” In Before Stonewall: Activists for Gay and Lesbian Rights in Historical Context, edited by Vern L. Bullough, 193-201. New York: Harrington Park Press, 2002.; McCreery, 192.

${ }^{71}$ Rose, 50.
} 
"transperience" to the National Observer, for example, he explained his premonitions of nothing less than "the evolution of communication between people." 72 After identifying the DCC as "too cautious," he left the organization and founded the "Miami Victory Campaign" and published aggressive, sardonic, and occasionally apocalyptic claims about Anita Bryant and Save Our Children, including one that warned "Anita Bryant is making Miami the key to either sustaining humanism or bringing back a possible repressive tyranny that will spread throughout the nation." ${ }^{173}$ Although his rhetoric was equally as ludicrous as others, Kunst soon became a gay iconoclast.

Unlike Kunst, Jack Campbell was wealthy, cautious, and well-connected. His Club Bathhouse chain was a profitable venture that typically included private rooms for what he hesitantly called "relationships." ${ }^{.74} \mathrm{He}$ claimed direct lineage to Queen Victoria and proudly displayed a "golden peanut" from Jimmy Carter's inauguration in his Coconut Grove mansion. Leading the DCC, he prohibited drag queens and "leathery extremists" because he claimed Miami’s homosexuals were "are a lot more conservative and less militant than they are in New York or San Francisco," adding "Most of the gay people living here have straight careers and don't want to be identified as gay." His lover, a young and muscular blonde, gave a clear indication of the homonormativity that he and Campbell shared; he recalled a group of straight people who visited their home and expected a "den of iniquity with statues of nude men." Instead, he bragged, "they seemed very pleased to see that we have a house with a washer and drier like everybody else."”75

\footnotetext{
${ }^{72}$ David W. Hacker, “Anita Bryant Tells Why She's Against Gay Rights,” the National Observer, March 12, 1977.

73 "Anita Bryant calls Dade County "A National Battleground," Press Release of the Transperience Center, March 21, 1977; McCreery, 192.

${ }^{74}$ Richard Steele with Holly Camp, "In the Gay Camp,” Newsweek, June 6, 1977, 19.

${ }^{75}$ Steele and Camp, ibid.
} 
Mass media descriptions of local gay life, always juxtaposed against Anita Bryant's world of religious piety and family life, fixated on Jack Campbell, his lover, and other white gay men who exemplified the lifestyle of Coconut Grove.

In the late 1970s, problematic depictions of gay life, evident in the New Times portrait of Jack Campbell's Coconut Grove, wove into a larger dialectic that affected how gay men and lesbians viewed and presented themselves. While the professional rhetoric of urban sophisticates pushed for comparisons with the Civil Rights Movement, more radical lesbian and gay activists compared Anita Bryant to Adolf Hitler. In doing so, gay and lesbian activists saw themselves as a persecuted and vulnerable minority on the verge of a new Holocaust. An extreme and bizarre example of this self-perception is evident in a 1978 flier distributed during the referendum in St. Paul: its shows a blurred photograph of a hanging white man who had been lynched, and it reads: "Dance, faggot." ${ }^{76}$ Another example, distributed during the 1977 Twin Cities Pride celebration in Minnesota, showed a smiling photo of Anita Bryant, painted green and superimposed over a photograph of a pile of dead bodies with the caption: "and your little dog, too!"77 By connecting images of genocide and lynching without noting their sources or context, the fliers connected racism and the holocaust to the plight of lesbians and gay men living without employment protection in the United States. Indeed, the only context is Anita Bryant reinvented as the Wicked Witch of the West; in doctoring her image to resemble the campy villain of The Wizard of $\mathrm{Oz}$, the Twin Cities Pride committee revealed a

\footnotetext{
${ }^{76}$ Target City Coalition, "Dance, Faggot!" flier, 1978, Anita Bryant Collection, Tretter Collection in Gay, Lesbian, Bisexual, and Transgender Studies, University of Minnesota Libraries.

${ }^{77}$ Twin Cities Pride Committee, The People United. The People Strong (Minneapolis, Twin Cities Pride Committee, 1977), Tretter Collection in Gay, Lesbian, Bisexual, and Transgender Studies, University of Minnesota Libraries.
} 
contradictory understanding of her role: she was silly, easily ridiculed, threatening, and a harbinger of genocide.

The media's depictions of wealthy white gay men presented them as having little need for employment nondiscrimination protections. That Campbell and others compared themselves to Civil Rights marchers or persecuted Jews seemed laughable; Coconut Grove was neither Wallace's Selma nor Hitler's Berlin. In an extensive article that appeared in New Times, Frank Rose described the "diversity" of gay Miami in this way:

"By day, unnoticed, gay doctors, lawyers, and schoolteachers go about their jobs while more flamboyant artists and decorators go quite visibly about their rounds. Slim, tanned, young men in brief bathing suits cruise favorite beaches. Other young men languidly sun themselves in public parks. By night, gay professional men gather over Chateauneuf du Pape and rack of lamb in the quiet of the Candlelight Club. Rougher sorts congregate in a blue-jeans-and-leather bar called the Ramrod. Male prostitutes stop by the all-night delis in Miami Beach for pastrami sandwiches. Staid homebodies retire to the quiet streets and houses in Coconut Grove." 78

In paying such close attention to lolling, young, and white gay men, mass media ignored queer parents, lesbians, and/or queer people of color, as well as broader examples of financial hardship, job discrimination, and anti-gay violence. Their portraits of white gay loungers who ate fancy French food bolstered a metronormative idea of urbanity, wealth, and sophistication that many gay men--especially Jack Campbell--we eager to perpetuate.

Campbell owned a lucrative bathhouse chain, The Club Baths, which was exemplary of this metronormativity. Like any other national chain, it packaged a commodity (in this case, clandestine and privatized gay sex) in the familiarity and comfort of a uniform environment that was available in most cities. But Campbell was not the only businessman to cash in on the burgeoning erotic marketplace. In 1974, faced

\footnotetext{
${ }^{78}$ Fuller and Camp, 19-22.
} 
with declining revenue in his Marlin Beach Hotel, Bill Hovan advertised in a gay magazine on a whim and, within three years, the Fort Launderdale hotel catered exclusively to white gay men. Fort Launderdale's apoplectic mayor, Clay Shaw, tried to shut it down, and Hovan complained that the Mayor's concern was provincial and retrograde: "This is a sophisticated area with about three million population," he claimed. "Why shouldn't we be able to enjoy a sophisticated lifestyle?" The Marlin Beach Hotel's sophistication was inherently tied to the anonymity of its visitors, who originated from cities across the country, and had an oppositional relationship with its immediate surroundings. Indeed, in a visit to the hotel while writing for New Times, Frank Rose overheard a 28-year old restaurant owner from New York City assure another guest that the hotel wasn’t just for people from New York: "I met Philadelphia yesterday afternoon," he said, "and Boston and Chicago, and last night I slept with Cleveland."79 Fort Lauderdale, Miami, and Florida itself, it seems, were only evident in the sunshine.

\section{The Gaycott and other National Endeavors}

Both sides of the fight in Dade County used media to exaggerate themselves and their opponents in order to attract more attention. Radical anti-gay Christians claimed that homosexuality heralded an apocalyptic collapse of civilization. At times framing itself as a godly crusader, the anti-gay movement used propaganda to recast the concept of homosexuality as pitiable, confused, and licentious threat. An example of this, collected by the Portland Town Council in 1977, is a small comic book mailed by "Christian

\footnotetext{
${ }^{79}$ Rose, 49 .
} 
Family Renewal." Following the life of Joe Ledbetter, a gay man who claimed to have disavowed himself of homosexuality through Christianity, the comic depicted homosexual feelings as a horrific, weeping eye that rode the backs of hapless young men and forced them to commit debaucherous acts. The protagonist, a happy teenage Joe, meets an older (but still young) man with a "blighted eye" on his back and, wearing a tank top, earrings, and studded wrist cuffs, the young man convinces Joe to commit "an act of homosexuality."

In the next frame, Joe opens a chest, only to find his very own eye monster that leads him through fifteen years of "'loneliness, dissatisfaction, alcoholism, drugs, attempted suicide—and crime." Along the way, Joe and his "blighted eye" show personifications of the "gay lifestyle:" a lecherous, sweaty alcoholic in a leather harness, a sneering sadomasochist with a whip, and a half-dressed men wandering about a nameless city in desperation. In one panel, Joe watches helplessly as a giant man in short-shorts descends on a "boy's camp" with his "blighted eye" leering ahead. "Joe discovered that many homosexuals and lesbians work in jobs like teaching and counseling," the panel reads, "where they had many opportunities to contact and seduce young people." The Blighted Eye depicted the fears of the anti-gay movement: that homosexuality was a communicable disease of "natural" human behavior, that the condition is spread, among other ways, by defiling the innocence of young children, and that homosexuality, once contracted, is incurable.

Bryant added to these anxieties the concept of a national, "militant," and urban homosexual force. In April 1977, the St. Petersburg Times ran a story out of San Francisco that announced a gay boycott--dubbed a "gaycott" by organizers--of the Florida 
Citrus Commission's products until it fired Bryant as the company spokeswoman. That outcome was unlikely; a representative of the Commission remarked that the company had received 2,000 letters after Bryant began her campaign, and ninety percent of those letters supported Anita's position. ${ }^{80}$ But the gaycott, organized by bisexual activist Dr. Alan Rockway, became the first of its kind on a national scale, as previous gaycotts in 1967 and 1974 were localized to the Los Angeles area. ${ }^{81}$ Gaycotts transformed into a nationally-scaled endeavor and gave gays and lesbians the sense that they constituted a form of economic clout, rather than a ragtag collection of urban constituencies. To organizers, the gaycott reified gay men and lesbians as a national "niche market" that added its unique needs to an "elaborately and intensely segmented" media market. "When the market becomes the arena of political action," Alexandria Chasin wrote in Selling Out, "gay and lesbian identity comes to bear a peculiar relation to (U.S.) national identity. ${ }^{82}$ That a relationship existed at all proved revolutionary among the United States' "gay leaders," but it also realized the worst fears of Bryant and other anti-gay figures: homosexual communities were the localized symptoms of a national moral ailment.

Anita Bryant invoked homosexual vices in large cities as a scare tactic during the "Save Our Children Campaign." In "Save Our Children/Let Us Marry,” an analysis of the "child protection" rhetoric of the gay and lesbian rights movement, Patrick McCreery noted that Anita Bryant's fears of homosexuals as child molesters proved to be a powerful rhetorical device that was affirmed by large media outlets. In May 1977, the Chicago

\footnotetext{
${ }^{80}$ United Press International, "Florida Orange Juice 'Gaycott' Picks up California Support,” St. Petersburg Times, April 22,1977, 7B.

${ }^{81}$ Alexandria Chasin, Selling Out: The Gay and Lesbian Movement Goes to Market (New York: St. Martin's Press, 2000), 148.

${ }^{82}$ Chasin, 146.
} 
Tribune ran a series of articles that fixated on Chicago as the epicenter of a child sex trafficking ring (one that was later "almost entirely disproved"), and Bryant was quick to use the articles--namely, their sensational headlines--in a full-page advertisement in the Miami Herald. Superimposed over the ad read the bold statement that exclaimed Bryant's last words with Ruth Shack: “THERE IS NO ‘HUMAN RIGHT’ TO CORRUPT OUR CHILDREN." ${ }^{\$ 3}$

Bryant's fears were confirmed in February 1977, when she lost a starring role in a thirteen-episode television show that Singer, the sewing machine corporation, intended to sponsor. She quickly blamed the canceled contract on the supposed influence of homosexuals in the media. ${ }^{84}$ But the cancellation was much more likely of her own making: Bryant had become a public relations nightmare, especially after her inarticulate and uncomfortable interviews began to mount. ${ }^{85}$ To a local paper in Miami Beach, for example, she bizarrely claimed "the right as a mother to be jealous of the atmosphere created by a flaunting homosexual. ${ }^{" 86}$ Newsweek reported that she pointedly asked male reporters if they were married. ${ }^{87}$ But an interview with Playboy was especially damning because it embodied the clear hypocrisies reified by a moral crusader chatting with a pornographic magazine. Written by Ken Kelley, who followed Bryant extensively for a short period in October 1977, "Cruising With Anita" featured an extensive back-and-forth

\footnotetext{
${ }^{83}$ McCreery, 192.

${ }^{84}$ Singer later rehired Bryant and stated that the executive was unauthorized to cancel the contract, but the show was never filmed: Hacker, ibid; Rose, 48. Bob Kunst was quick to point out the irony of Bryant losing her job as she attempted to prevent employment nondiscrimination: Kunst, "A National Battleground.".

${ }^{85}$ Ken Kelley. "Cruising With Anita," Playboy Magazine 25 (1978): 78; Fuller, Tony and Holly Camp, "Anita Bryant vs. the Homosexuals," Newsweek, June 6, 1977: 16-22.

${ }^{86}$ Ellen Seldin, "Anita Bryant: She Wants to get back to Being a Mommy, Again," Miami Beach SunTimes, March 6, 1977, front page.

${ }^{87}$ Richard Steele with Holly Camp, "In the Gay Camp," Newsweek, June 6, 1977, 21.
} 
between Bryant and Kelly that underscored her unfamiliarity with sexual topics. She momentarily forgot the word "sadomasochism." She equated gay claims of a minority status with the silliness of such claims coming from "nail-biters, dieters, fat people, short people, and murderers." Kelly also caught her in several logical fallacies:

Playboy: ...As a Social Scientist, [Alfred] Kinsey claimed that 37 percent of the American population--and this was in the late 1940s--had committed at least one homosexual act.

Bryant: But that doesn't mean they were homosexuals.

Playboy: But wait, just a moment ago, you said that committing the homosexual act defined the homosexual being.

Bryant: Yeah, I did say that the sex act constitutes...Look, what I'm saying is that people experiment--they may do it a couple of times. It doesn't mean that they are practicing homosexuals for life. Some people will try it out just once for the kicks--out of curiosity. They can still be forgiven for that $\sin ^{88}$

In less than a page, Bryant contradicted herself yet again, calling bisexuality "a dangerous place to be" that involved a precipice situated between forgiveness salvation on the one hand, and an inescapable life of sin on the other, while she simultaneously suggested that it was the best of two worlds. "They're having their cake and eating it too, you see," she explained.

While Bryant's strange behavior and muddled arguments negatively impacted her national image, it had a positive effect on SOC's local campaign. The organization obtained more than sixty-four thousand signatures in support of the referendum. Having needed only then thousand to get the ballot passed, they forced the Miami-Dade Metropolitan Commission to vote 6-3 in favor of putting the issue to a special vote ("no" votes, according to local law, were votes to rescind it immediately). In a front page story

${ }^{88}$ Kelley, 85. 
on the March vote, the Miami News noted that one of the dissenting Commissioners, Robert Brake, cited the number of signatures as an indication that the vote would be a redundant expression of the will of Miami voters: "We had gotten enough signatures on our petitions to indicate the feeling of the citizens that this ordinance should have been repealed immediately," he said. "It was extremely poor judgment by the commission to do this." ${ }^{89}$ Reacting to the vote, Bryant gave an early indication that she was ready to take the fight beyond the local sphere. "We shall not let the nation down," she said. Twelve weeks later, on the day of the vote, June 7, 1977, capping the end of a "bitter and increasingly bizarre" campaign, the results came back, and Miamians voted approximately $200,000-88,000$ for repeal. ${ }^{90}$

For many gay and lesbians activists, the timing--if certainly not the vote itself-was serendipitous. It occurred less than three weeks before the last weekend of June, when over a dozen local Gay Pride organizers had scheduled commemorations of the seventh anniversary of the Stonewall Riots. Before 1977, gay pride festivals were attended by small crowds in select cities; they were political, but in the same respect that the ubiquitous political marches of the Vietnam Era were political. Bryant's victory in Dade County gave activists something to organize around, or, more specifically, a perfect villain to mobilize against. Perhaps unsurprisingly, the most visible prides-as-protests occurred in New York, where twenty-five thousand marched in a mile-long parade on Fifth Avenue, and in San Francisco, where one-hundred thousand protested against Bryant and the recent anti-gay murder of Robert Hillsborough, a local gay man. ${ }^{91}$ The two

\footnotetext{
${ }^{89}$ Morton Lucoff, “Countywide Vote on Gay Rights,” Miami News, March 15, 1977, front page.

${ }^{90}$ Associated Press, "Gay Rights Law Beaten in Miami," Pittsburgh Post-Gazette, June 8, 1977, front page.

${ }^{91}$ United Press International, "Homosexuals on March for Rights, Against Anita Bryant," Montreal Gazette, June 27, 1977, 41.
} 
demonstrations were unprecedented mobilizations of lesbian- and gay-identified men. The role of Anita Bryant as a villain dovetailed with a commemoration of rioting; she gave a face to a nameless fear and hatred in the same way that the Stonewall riots reified political retaliation. Thus, Bryant's personification of anti-gay hatred folded into gay pride as a chief commemorative model.

The vote created a difficult year for Bryant and the city of Miami. In July, a federal judge barred Bryant and her organization from using the "Save Our Children" name after Save the Children, a Connecticut-based charity dedicated to impoverished children, filed suit against her. ${ }^{92}$ Gay organizers in Minneapolis, led by radical activist Jack Baker, responded to the repeal with a one-column ad in the Miami Herald that invited lesbian and gay Miamians to relocate to Minneapolis-St. Paul and "trade a rotten palm for a thriving pine." ${ }^{93}$ As Bryant was preparing to publicize her new tell-all book, The Anita Bryant Story, Dick Shack's Agency for the Performing Arts formally severed ties, leaving her without a close relationship with much-needed professional representation. ${ }^{94}$ By October, faced with the prospect of losing her position as a spokesperson of Florida Citrus, she used biblical terms such as "crucify" to frame herself as a martyr for the cause. ${ }^{95}$ Invited to the Today Show in November, she expressed support for a federal law banning homosexuality and claimed she was blacklisted by unnamed media interests in Hollywood, while gay marchers outside of Radio City Music

\footnotetext{
${ }^{92}$ Despite the suit, historians and contemporaneous media have continued to use the "Save Our Children" name: Associated Press, "Group Ordered to Drop 'Save Our Children' Title," Palm Beach Post-Times, July 16, 1977, B2.

${ }^{93}$ Associated Press, "Homosexuals Welcome," St. Petersburg Independent, July 8, 1977, 3 A.

${ }^{94}$ Associated Press, “Agency Drops Anita Bryant,” Lakeland Ledger, July 7, 1977, 2 A.

${ }^{95}$ United Press International, "Anita Bryant Says She is Tired of Being 'Persecuted," St. Petersburg Times, October 28, 1977, 8B.
} 
Hall burned her in effigy. ${ }^{96}$ She finally shortened her New York visit after she received several death threats and learned of an impending march of thousands on her hotel. ${ }^{97}$ At a concert in St. Petersburg, Florida, hundreds of gay rights protesters interacted with two thousand concert attendees and a small contingent of the Ku Klux Klan. Despite two bomb threats, the concert went as planned, but two wigged protesters, whom the St. Petersburg Times identified as "self-professed gay men," dressed in women's clothing, entered a women's restroom and greeted outraged women who quickly called the police. ${ }^{98}$

Finally, in December 1977, NBC dropped Bryant from a recurring role as co-host of the Florida Orange Bowl Parade. The network denied that she was fired due to her activities; it chose her replacement--Rita Moreno, star of West Side Story--to give the show a "more international flavor." 99 Beyond a coded suggestion that the show chose Moreno because they wanted to represent the growing community of nonwhite Floridians, it selected her because she was not controversial. But the cancellation marked the most tangible of many symbolic shifts in Bryant's transformation from "local mother" to "national crusader," as the controversial nature of her national presence made her an impractical choice for narrating the distinctly-Floridian event. She was, in other words, no longer an appropriate symbol for Florida. "I knew what I was up against," Bryant told Playboy in 1978, "the homosexuals in Dade County had amassed support from homosexuals around the country and they had the active backing of a wide range of

\footnotetext{
${ }^{96}$ Associated Press, "Anita Favors U.S. Law Outlawing Homosexuality, Miami News, November 3, 1977, 4A; "Threats Won't Stop Anita Bryant," Toledo Blade, November 3, 1977, 26.

97 "Anita Bryant Leaves New York Because of Threats to Her Life," Ottawa Citizen, November 3, 1977, 39.

${ }^{98}$ Kelly Scott, "Anita Bryant, Concert Brings Clash of Gay, Straight Lifestyles," St. Petersburg Times, November 9, 1977, 1B.

99 “Anita Bryant Won’t Co-Host Orange Parade," Florence Times-Daily, December 8, 1977, 14.
} 
liberal politicians. ${ }^{100}$ But instead, Bryant was up against a changing state that had tired of her.

Also contrary to Bryant's claims, there is little indication that she had any idea of what awaited her. Indeed, her interviews suggest that she was completely unprepared for national recognition as the personification of anti-gay sentiment. Often veiled by the confident and knowing smile of an actress, her unpreparedness occasionally revealed itself, as her pitiful post-pie emotional breakdown in Des Moines clearly illustrated. She was still a spokesperson in many respects, one who had with little direct involvement and sparse knowledge of what she actually sold. Indeed, immediately after the repeal in Dade County, Bryant became so busy traveling that SOC organizer Robert Blake complained she "has hardly been in [Miami Beach] long enough to say hello and goodbye" to the staff. Flush with victory, Bryant had left Miami behind and took to the spotlight on a national stage and, as the national solidarity of their well-attended local pride marches attested, gay and lesbian activists were right behind her. ${ }^{101}$

\footnotetext{
${ }^{100}$ Kelly, 79.

${ }^{101}$ Daniel Saint Albin-Greene, “Anita Will Find Washington, D.C. is A Capital Place for Gays," The National Observer, June 20, 1977, front page.
} 


\section{Chapter 3: Surrender in the Emerald City}

The Loss in Eugene, 1974-1978

On December 18, 1974, the City Commission of Portland, Oregon considered a resolution to ban discrimination against city employees on the basis of sexual orientation. According to the Oregonian, the state's largest newspaper, the commission's vote became "one of the most politically risky issues to ever hit City Hall." ${ }^{102}$ During four hours of heated public testimony, a packed room of priests, gay community representatives, concerned parents, and local politicians focused on the law's legal impact and symbolic possibilities. Reacting to one of several recommendations for a popular vote on the issue, a representative of the Counseling Center for Sexual Minorities warned of "unmitigated disaster." Representing Citizens for a Decent Oregon, a local priest claimed that the ordinance posed a threat to "the very life" of the nation. But citizens were not alone in making hyperbolic claims: one dissenting commissioner argued that the ordinance presaged discrimination claims based on inane personal preferences, including "going home barefoot," while another, in a foreshadowing Save Our Children's rhetoric, expressed his fears for local children under the watch of homosexual park employees. ${ }^{103}$

Mayor Neil Goldschmidt, a voting member of the Commission, also addressed the room; he read from a hastily-written speech and argued for a "yes" vote without regard to its political implications. "I will submit my record to the voters in a year and a half," he said. "If [the ordinance] is so repugnant...it will be seen by the outcome." At times, he argued, the government was responsible for supporting unpopular causes in the broader

\footnotetext{
${ }^{102}$ Huntly Collins, "McCready Puts Political Courage on Line," Oregonian, December 24, 1974, page A15.

${ }^{103}$ Huntly Collins, "City Bans Homosexual Bias from Employment Policies,” Oregonian, December 19, 1974, front page.
} 
interest of the public good. ${ }^{104}$ Two other Commissioners agreed, and the ordinance passed 3-2. A year and a half later, as Goldschmidt unexpectedly predicted, a white panel truck parked in downtown Portland with a large sign that questioned the mayor's voting record on gay rights: "Did Mayor Goldschmidt vote against God? Goldschmidt votes...

homosexuals $\mathrm{OK}$ as policemen!" ${ }^{105}$ But the unidentified truck's hand-painted message seemingly had little resonance with Portland voters during the 1976 city primary, and Goldschmidt was handily reelected to a second term. No serious repeal effort formed in response to the nondiscrimination resolution, and the issue seemed put to rest.

The small stir created by municipal nondiscrimination legislation in Portland ended with vastly different results than the "culture war" that rocked in Miami-Dade County two years later. A comparison between the two cities gives some context to the different outcomes. Miami and Portland were both major sea ports with some similarities--in particular, comparable population sizes and status as the densest city of their state. But, at opposite corners of the country, the two cities had clear demographic, cultural, political, and physical differences. ${ }^{106}$ In no small part, the fates of the nondiscrimination laws reflected the vast differences between them. Portland betrayed its roots as staid old lumber town above the confluence of the Columbia and Willamette rivers, and it framed a one hundred mile-long region in Oregon, the Willamette Valley, where seventy percent of the state's population lived on only twelve percent of its land

\footnotetext{
${ }^{104}$ Collins, "City Ban Homosexual Bias," page 28.

${ }^{105}$ Photographs taken on April 22, 1976 (creator unknown), Portland Town Council Records, Oregon Historical Society, box (10-2), "Personalities: 'Goldschmidt-K'" folder. April 22, 1976

${ }^{106}$ Populations of the cities proper: from 1970-1980 Portland lost population $(382,619$ - 366,383), and Miami gained (334,859 - 346,385). It is important to note the differences: Multnomah County $(562,640)$ was considerably smaller than Dade County $(1,267,792)$, and the vote in Portland affected a population that was less than one third of the population affected by the vote in Miami-Dade County. Miami had also recently lost its title as Florida's largest city to Jacksonville, which doubled in population between 1960 and 1970 as the result of aggressive suburban annexation.
} 
area. ${ }^{107}$ Miami, by contrast, was a sprawling subtropical melting pot of Jewish retirees, African-Americans, and Cubans immigrants. While Portland struggled to shed its industrial past, Miami was in the mist of becoming the southern United States' first "world city."108

If Portland and Miami proper were strikingly different regional centers of comparable size, Miami and the small city of Eugene had few, if any, direct similarities. In Oregon, the Willamette River was home to three large urban conglomerations that marked its valley's upper, middle, and lower sections: Portland to the north, at the Oregon-Washington border; Salem, the state capital, in the middle; and Eugene to the south. Eugene, the seat of Lane County and home of the University of Oregon, formed a metropolitan area with its eastern neighbor, Springfield, a town that boomed as Eugene decentralized in the 1960s. ${ }^{109}$ Its population was well-educated, if "not particularly affluent," and its status as a haven for the nuclear family was well-understood; Springfield later inspired the setting of the popular television cartoon The Simpsons."110 Released in 1978, the popular film Animal House further asserted Eugene's role as a locus of a more raucous form of collegiate heterosexuality--at least among locals who

\footnotetext{
${ }^{107}$ HR Richmond, "Unique Public Interest Law Group Supports Oregon Land Use Program," Land Use and Zoning Law Digest, vol. 31: issue 10, 435-484.

108 Jan Nijman, Miami: Mistress of the Americas (Philadelphia: University of Pennsylvania Press, 2010), vii-viii.

${ }^{109}$ H. Dearborn and J. Goicochea Duclos, "1930 and 1970 Population," Willamette River Basin Planning Atlas: Trajectories of Environmental and Ecological Change (2nd ed.) (Corvallis, OR: Oregon State University Press, 2002), 54-55:

http://www.fsl.orst.edu/pnwerc/wrb/Atlas_web_compressed/5.Human_Populations/5c.193070pop_web.pdf.

${ }^{110}$ Dan Pope, "'We Can Wait. We Should Wait.' Eugene's Nuclear Power Controversy, 1968-1970, Pacific Historical Review 59 no. 3 (August 1990): 351; on The Simpsons, creator Matt Groening explained that he was inspired by Springfield's name while growing up in Portland, but explicitly noted that the inspiration came from Springfield's ubiquitous name.
} 
could identify the filming location as the University of Oregon. ${ }^{111}$ Nestled at the base of the densely-forested foothills of the Calapooya Mountains, Eugene was also one of several cities, including Seattle, WA; Syracuse, NY; Wichita; and Sydney, Australia that adopted the "Emerald City" nickname, a Wizard of $O z$ reference that became eerily fitting for the small city in $1978 .{ }^{112}$ It was the last stop on a strange journey that involved Kansas, strange characters, and, in some minds, either a good witch or a very wicked one. In this section, I focus on the 1978 referendum of Eugene's employment nondiscrimination ordinance as the last of four that Anita Bryant and the "Save Our Children" campaign targeted between the summers of 1977 and 1978. Compared to Miami, where unwitting locals were subjected to the competing attentions of national media, "professional" gay activism, and the anti-gay claims of Anita Bryant as the embodiment of local wholesomeness, Eugene attracted limited media attention, it concerned gay and lesbian organizations that were pointedly based in Oregon (if not Eugene exclusively), and it felt the influence of Anita Bryant as a faraway national figure. That Bryant represented the "local" in Miami and the "national" in Eugene indicated the contradictory aspects of her role in the national narrative of queer history; her transformation partly inspired--but did not exclusively cause--changes in the gay rights movement and the anti-gay countermovement that came to be interpreted through the lens of Dade County's aftermath. The dramatic political and rhetorical changes between the fights in Miami and Eugene challenge the anti-gay crusader's role in inspiring an

\footnotetext{
${ }^{111}$ Matty Simmons, Fat, Drunk, and Stupid: The Inside Story Behind the Making of Animal House (New York: St. Martin's Press, 2012) 84.

112 See: Mary Boone, Uniquely Oregon (Chicago: Heinemann Library, 2004), 5; Joan Fitzgerald, Emerald Cities: Urban Sustainability and Economic Development (London: Oxford University Press, 2010), 8; Matthew W. Klingle, Emerald City: An Environmental History of Seattle (New Haven: Yale University Press, 2007); Gordon Waitt, "Playing Games With Sydney: Marketing Sydney for the 2000 Olympics," Urban Studies 36 no. 7 (1999): 1064.
} 
unprecedented politicization of gay men and lesbians, because they were rooted in local nuances that can be better understood through the lenses of geography, history, and politics--or what I have referred to in this paper as queer localization.

To better understand the 1978 gay rights referendum, I will examine the complex relationships between Portland, Eugene, and Lane County residents as an interacting network of influences between representations of the big city, the smaller city, and the rural community. In Eugene, unintentional associations with Anita Bryant and national attention proved to be one of many setbacks to nondiscrimination supporters, whose resulting loss led Portland media to question the Emerald city's "liberal" identity. But the imposition of Portland's cosmopolitan arbitration was extremely limited, as compared to the influence New York and San Francisco exerted over Miami. In fact, Portlanders experience a complete reversal of the large city/small town relationship that was evident in Miami in 1977 and in Brandon Teena's Falls City in 1993. In the aftermath of Eugene's loss of gay nondiscrimination legislation, Mayor Neil Goldschmidt abruptly ceased demonstrating his support for the gay and lesbian community because he feared that Eugene's vote would inspire a similar backlash downriver. After he made an official proclamation of "Gay Pride Day" in 1977, he faced a subsequent recall campaign and refused to issue a similar proclamation in 1978. If Eugene residents feared the influence of Portland and San Francisco, the latter two should have feared the influence of Eugene.

Two contemporaneous referendums give context to the localized nuances of an urban/rural divide in the Willamette Valley. The first concerned a state law, Oregon's Senate Bill 100 (SB 100, 1973), which established a Land Conservation and Development Commission (LCDC) to review local urban development plans for 
compliance with state guidelines. Intended to guide the growth of Oregon cities and limit their sprawl, the law inspired a 1976 general election referendum, Measure 10, that aimed to rescind SB 100's mandated coordination between local cities and the state government. In a 1979 analysis of the results, "Urban-Rural Class Conflict in Oregon Land Use Planning," Jerry Medler and Alvin Mushkatel noted that Eugene, with about 76,000 residents in 1970, was joined by "numerous smaller towns and a significant rural population" to form the broader population of Lane County. The authors found that the residents of wealthier and well-developed cities, which included Eugene, Salem, and Portland, voted in support SB 100, while poorer and less-developed--that is, more rural-residents, including those who lived beyond Eugene's boundaries in Lane County, voted against it. ${ }^{113}$ The lumber industry, Oregon's primary natural resource economy and a mainstay of many rural communities, underwent rapid changes in the 1980s and 1990s, and the idea of an amalgamated "rural Oregon" became even less apparent. As SB 100 had initially revealed, "two small-town Oregons" emerged in the towns that suffered and those that prospered. Lane County exemplified a complicated interaction between the two towns, as it was both a major timber producer and a home to a growing concentration of urban residents. It was both urban and rural in a way that challenged either definition. ${ }^{114}$

The other referendum focused on a late-1960s nuclear power proposal.

Overwhelmingly supported by Eugene residents in 1968 and rejected in a referendum two years later, nuclear power became a locus of a local/outsider conflict that later loomed

\footnotetext{
113 Jerry Medler and Alvin Mushkatel, "Urban-Rural Class Conflict in Oregon Land Use Planning," Western Political Quarterly 32 no. 3, (Sep. 1979): 338-349.

${ }^{114}$ Michael Hibbard. "Land Use Planning and the Future of Oregon's Timber Towns." In Planning the Oregon Way: A Twenty-Year Evaluation, edited by Carl Abbott, Deborah Howe, and Sy Adler, 189-201. Corvallis, OR: Oregon State University Press, 1994.
} 
above the 1978 referendum. In an analysis of the controversy, Dan Pope noted that Lane County was a large area, equivalent in size to the state of Connecticut, with far-flung and diverse concentrations of population. In the 1968 general election, the local power authority put a charter amendment to voters that requested $\$ 225$ million in bond sales for (the implied) construction of a nuclear reactor. Voters approved the amendment by a twoto-one margin in nearly every precinct--even as they rejected two tax levies that same day. But to implement construction of the plant, the power authority sought the expertise of bankers, lawyers, engineers, and other outsider-experts: "This reliance left it vulnerable to later charges that community interests were being subordinated or neglected by these cosmopolitan organizations," Pope observed. "When the time came to defend its project to Eugene's voters, the utility found it difficult to reassert its democratic roots." 115 In a parenthetical note, Pope explained that the issue may have initially passed without much controversy because most of the opponents lived outside of Eugene's city limits in 1968 and they were thus ineligible to vote. In a 1986 interview, one of the main nuclear power opponents remembered that supporters who lived in Eugene never cast their foes as Lane County "outsiders"--a strategy, she believed, that would have worked well. ${ }^{116}$

The two controversies, one localized to Oregon, the other to Lane County, each suggested that the "urban" and "rural" and the "local" and "outsider" were positional definitions that folded into a larger understanding of Portland as the "big city," Eugene as a "small city," and Lane County as "rural." In terms of the 1978 Eugene referendum, the relationship between these geographies helped advertise Portland as a conceptual epicenter of lesbian and gay culture in Oregon that became an "outsider" to Lane County

${ }^{115}$ Pope, 355.

${ }^{116}$ Pope, 356. 
residents who dominated the anti-gay side of the fight. The controversies can also be understood as case studies that test the applicability of Jack Halberstam's "metronormativity" outside the realm of queer scholarship. In both cases, through the lens of Halberstam's definition of metronormativity, we can identify "normativity" as the normalizing endeavors of a cosmopolitan outsider (the LCDC, nuclear experts) that attempted to map a time-based endeavor (urban development, construction of a nuclear plant) to a landscape framed by a "rural" and "urban" dichotomy. Metronormativity applies, but only if it is freed from the polar arrangement it analyzes.

\section{“A Nice, Quiet Local Issue”}

The relationship between Portland and Eugene can be understood through the lens of the state's largest daily newspaper, the Oregonian, which was headquartered in Portland and focused on news around the state. The paper focused on the introduction, adoption, public opposition to, and repeal of Eugene's short-lived nondiscrimination measure in sporadic and short articles that never made it to the front page of the local and regional section. Instead, the articles shared space with gloomy local news items and oddly-juxtaposed advertisements and cartoons. The first story on the measure--printed before it went to the Eugene City Council on October 24, 1977--competed with other local headlines that carried a dark foreboding: "One Injured in Zoo Mishap," "Wreck Kills Baby," "Woman Arrested in Shooting Death," and "Fire Damages Home;" it also shared the page with advertisements by Meier and Frank, Portland's major department store, that extolled the virtues of vacuums, rug cleaning services, beauty salons, and crockpots. 
At the top of the page, the story's no-nonsense headline: "Gay Rights Bill Goes Before Eugene Council Monday," carried an AP signature that suggested a modicum of national attention to the story. This attention likely related to the measure's timing; Larry Monical, a supporter, noted that the measure was directly inspired by the referendum in Dade County four months earlier: "There is a surprising amount of community support for it," he said," particularly after Anita Bryant. She made people mad and aroused a lot of support we might not have otherwise had." ${ }^{117}$ Despite its place in the pages of local media, the ordinance in Eugene--like the other ordinances to the east--inspired a flurry of communication with local representatives. One of the city's eight council members, Jack Delay, reported receiving more calls on the issue of gay rights that he did on all others combined. Another council member, Helen Taff, explained why she would vote no in terms of fearing the influence of San Francisco: "I feel it would lower the reputation of the community...San Francisco is a city I dearly loved, and look how much of it has been downgraded. I can't help but feel that being sympathetic to the homosexual cause is going to make it much easier for the same thing to happen to Eugene.” Though she was unclear about the nature of San Francisco's downgrade, it was clear that Taff feared its northward spread, and some of her constituencies shared that fear. Before the council even cast votes on the measure (it passed 5-3); an informal group called Coalition for the Concerned had collected hundreds of signatures against it. ${ }^{118}$

The aversion to the influence of Californians, shared amongst many Oregonians, extended far beyond the association with San Francisco's status as the locus of a queer other. In part, the hostility toward outsiders resulted from the state's accelerated

${ }^{117}$ Linda Kramer, "Gay Rights Bill Goes Before Eugene Council Monday,” Oregonian, 19A. 118 Ibid. 
population growth; in the decade between 1965 and 1975, the state population rose-overwhelmingly due to migration--by one-sixth. ${ }^{119}$ Amid this hyperbolic growth, during a nationally-televised Jaycees conference in 1971, outspoken Oregon governor Tom McCall, who had a reputation for giving outsiders the "cold shoulder," told potential visitors "Visit us often, but for heaven's sake, don't move here to live." ${ }^{120}$ By 1975, the Associated Press issued its readers the hesitate invitation "It's O.K. to move to Oregon Again" and reported that, despite McCall's unfriendly message, Oregon was the seventh fastest-growing state in the country. ${ }^{121}$ According to Preston L. Schiller, McCall's aversion to growth, evident in his support of SB 100 and the Land Conservation and Development Commission (LCDC), came from his fears of "Californication" reducing the quality of life shared by native Oregonians. ${ }^{122}$

The Advocate repeated the local fear of Eugene as a Californicated colony. "Prorepeal forces stayed away from moral and religious issues until shortly before the election," it reported, "maintaining that the issue was one of "special privileges to homosexuals'...A few days before the election, nevertheless, ads appeared from some church groups as well as one headlined "An Open Letter From a Former Homosexual" that asked, "Do we want to follow in the footsteps of San Francisco?"123 In an editorial, the Eugene Register-Guard had supported the city council's action before their imminent

\footnotetext{
${ }^{119}$ David S. Brader, "Here Comes High Tech: Oregon's Economic Climate Rapidly Changing," Bend Bulletin, March 3, 1985, 1B. 120

${ }^{121}$ Associated Press, “It’s O.K. to move to Oregon Again,” Spokane Spokesman-Review, December 9, $1975,7$.

122 Preston L. Schiller, “Connections Within the Western U.S.-Canada Border Region: Toward More Sustainable Transportation Practices," Transboundary Policy Challenges in the Pacific Border Regions of North America, ed. Donald K. Alper, John C Day, and James Loucky (Calgary, University of Calgary Press, 2008), 100.

${ }^{123}$ Elenore G. Pred, “A Loss in Eugene,” The Advocate, issue 244, June 28, 1978, 15.
} 
vote; the editors argued that the addendum did not grant "special rights" to homosexuals, and could be reversed at any point in time. They nonetheless expressed regret for the council's foray into gay rights and feared a referendum was imminent. "Eugene could become another public opinion battleground in the pattern of Miami," the paper warned, "where, earlier this year, a highly emotional special election campaign was led by singer Anita Bryant to overturn a city ordinance that would have prohibited discrimination against homosexuals by landlords and employers." 124

Less than five months later, on May 1, 1978, the Oregonian nestled a news item amid a television program schedule, a Doonesbury cartoon, advertisements for yet more vacuums, and the daily weather report. "An informational but not emotional campaign is promised by both sides involved in the gay-rights referendum that will face [Eugene] voters May 28," it read. “Anita Bryant, who became a symbol of anti-homosexual rights forces in Dade County, Fla., won't be involved in Eugene." The informal anti-gay group, Coalition for the Concerned, had become a large organization responsible for the referendum, Volunteer Organization Involved in Community Enactments (VOICE), and claimed that it did not need or want Anita Bryant's assistance. One of the VOICE organizers, Maureen Gieber, put it bluntly: "She is not coming. She doesn't want to be a target, and we want to keep this a nice, quiet local issue." ${ }^{125}$ But, despite its marked physical separation from Bryant--"we don’t need her," a volunteer said--it was clear that VOICE felt inspiration from the successful referendums in Dade County, St. Paul, and Wichita. The newspaper had purposefully introduced its first story about the Eugene

${ }^{124}$ Eugene Register-Guard editorial staff, "Vote on Gay Rights?" Eugene Register-Guard, October 28, 1977, 12A.

${ }^{125}$ Clay Eals, "Eugene Groups Gird for Vote on Gay Rights," Oregonian, May 1, 1978, 3M. 
referendum with Bryant, even if it did so in the back pages. It was clear that struggle in Eugene was contextualized by Bryant's presence--or absence--as a nationally-recognized anti-gay personality.

Curiously, Maureen Gieber had written an editorial to the Register-Guard more than a decade earlier that complained of campaigns that used fear and misinformation to purposely mislead the public vote. Faced with the prospect of introducing fluoride to the local water supply, she noted that less than two-dozen people were responsible for organizing a campaign against fluoridation: "they work on people's emotions," she wrote in 1964, "because they know that if these people would calmly weigh the scientific facts as to the safety of fluoride they would be in favor of it." ${ }^{126}$ By 1978, Maureen Gieber became the subject of local media attention when she decried the perceived pro-gay bias amongst reporters at a thirty-minute press conference that announced the formation of VOICE. "Much of the...conference turned into a sparring match between Mrs. Gierber and several reporters who argued with her, "reported Don Nelson of the Eugene RegisterGuard. As reporters began to leave, Gieber warned them that the issue was not yet over, and that they had "wasted" too much time focused on the morality of the homosexuality, and not on the other concerns of VOICE constituencies. She complained that anti-gay organizers were often cast as "religious fanatics" or "narrow-minded bigots" and suggested that the media assisted in the portrayal.

Unlike Dade County, the outcome of the Eugene referendum was all but certain. VOICE had collected more than 10,000 signatures--1/6 of the city's total voters--to put the ordinance to a special referendum. By May, the anti-gay group expected to win, and it

\footnotetext{
${ }^{126}$ Maureen Gieber, "Rinse Preferred,” Eugene Register-Guard, October 30, 1964, 15A.
} 
hoped to do so by a wide enough margin to warn other Oregon cities that nondiscrimination ordinances were unwelcome across the state. If ECHR had five times the resources, $\$ 25,000$, than VOICE's $\$ 5,500$, it still faced serious disadvantages. ${ }^{127}$ Its name was associated with two unsuccessful gay rights organizations--the Dade County Coalition for Human Rights (DCC) and St. Paul Citizens for Human Rights (SPCHR)-that used problematic "human rights" rhetoric, advocated by Ethan Geto and other metropolitan experts, in their fight against their respective referendums and in the face of Bryant's visibility. ${ }^{128}$ The precedent set by ECHR's namesakes did not bode well; DCC's loss in Miami-Dade was a fresh memory, and SPCHR lost when voters rescinded St. Paul's ordinance by a 2-to-1 margin on April 25. To make matters worse, Kansas added to the losses--just as the Eugene campaign intensified--when Wichita voters overturned their ordinance by a 5-to-1 ratio on May 9 .

Beyond the magnitude of their losses, the gay rights struggles in Miami, St. Paul, and Wichita gave ECHR yet another disadvantage by association: the other cities became the focus of a media circus that Eugene voters attributed to gay rights and wanted no part of. As the 1977 pie incident had suggested in Des Moines, reporters, anti-gay zealots, and gay rights radicals were eager to follow their ringleader, Bryant, wherever she went. VOICE clearly understood the local aversion to entering that fray, as their call for a "nice, local issue" suggested, and accordingly, it placed a large distance between itself and Bryant. Strangely, this put ECHR at still another disadvantage; as Larry Monical had

\footnotetext{
127 "Eugene Groups Gird for Gay Rights," ibid.

${ }^{128}$ See: "St. Paul Citizens for Human Rights" collection, Tretter Collection in GLBT Studies, University of Minnesota Libraries. In Wichita, locals organized as the "Homophile Association of Sedgwick County," and passed a nondiscrimination ordinance that met a different kind of referendum. While Witchita is not part of this study, it is interesting to note the ordinance had the support of local Catholics: "Religious Caucus Backs Gay Rights," Wichita Eagle, May 6, 1978; "Catholics Disagree on Gay Ordinance," Wichita Eagle, May 8, 1978. 38; http://www.youtube.com/watch?v=87sPFeyzGrY, retrieved 3/2/2012.
} 
noted to the Oregonian, Bryant had served as a negative inspiration to the gay rights side, and not the anti-gay side. Thus, Bryant had unknowingly become a rhetorical Trojan horse in Oregon, used by gay rights advocates in a way that unintentionally damaged their credibility as locals from within. ECHR had become, in other words, the group that brought Anita home.

The anxiety over Bryant's presence was justified. She had encouraged the other repeals with great fanfare in Wichita, where she delivered a jeremiad to crowds of the faithful shortly before their overwhelming vote. "Wake up people," she told the crowd as she held back tears. "Wake up before it's too late." ${ }^{129}$ The attention to Wichita inspired a mass protest on Castro Street in San Francisco that became immortalized in the popular movie Milk (2008). In one scene that resembled the opening of The Brady Bunch, gay organizer Clive Jones called friends from a San Francisco telephone booth with a hurried message: "Hey, we're losing Wichita tonight, so rally tonight, Sundown, at Market Street and Castro, okay?" As they demonstrated in Miami in 1977, and as the movie later glamorized, queer San Franciscans were willing to pile into cars or take to the streets to express solidarity if they felt it was needed; if they weren't willing to make the day's journey to Wichita, where a loss was almost certain, they were certainly willing to mass on Castro Street. Further, at an eight hours driving distance from Eugene, they were easily capable of heading north on Interstate 5 to save a city they expected to win. ${ }^{130}$

Anxieties over the antics of radical outsiders permeated both sides of the fight. In the midst of the St. Paul referendum, for example, Bryant penned a letter to Save Our

\footnotetext{
${ }^{129}$ Associated Press," Bryant Tearful at Wichita Rally," Lawrence Journal-World, December 7, 1977, page 7.

${ }^{130}$ Clay Eals, “Eugene’s Liberal Image: A Myth?” Oregonian, B1.
} 
Children members that warned of the threats that militant homosexuals posed to the Rev. Richard Angwin, who lead Citizens Alert for Morality--the group that fought for a repeal of Minnesota's second gay rights ordinance. “A bloody axe was left on his daughter's bed," she wrote, "his sermons were ripped and his bible stomped so hard you could see the footprints, and their pet poodle [was] blown to bits." ${ }^{131}$ Regardless of its veracity, her claim promulgated anxieties over the violence that "militant homosexuals" supposedly threatened. Broadly, the claim highlighted the kinds of rhetoric that surrounded the heavily-publicized referendums in the three other target cities. If Eugene residents could not determine whether gay activists were really as violent as Bryant suggested, most were completely uninterested in actually finding out for themselves.

The association between outsiders, Anita Bryant, and antagonizing behavior did not always come from distant cities. The Capitol Forum, a Salem, Oregon-based gay rights group, made a flippant call that invited Bryant as "The Minute Maid of Dade" to try her campaign in places beyond Florida:

“"'Well, Anita, you've stirred up quite a hornet's nest. And believe me, there's more sting there than you ever imagined...in the name of 'God,' you'll take on America. But, unfortunately, all of America is not as conservative or full of retirees as Dade County... I can't wait for you to take on such towns as San Francisco, Chicago, New York, Seattle, or even little 'ol Portland, Oregon." 132

A much more disturbing example of Bryant's influence on susceptible Oregonians emerged in Portland, where the PTC received an aggressive and anonymous threat

\footnotetext{
${ }^{131}$ Letter from Anita Bryant to supporters, (undated, spring 1978), Portland Town Council Records, coll. 256., box 2/12, Oregon Historical Society. Bryant's claim is surprising and, if true, chilling. I never encountered a reference to these purported attacks in my research on the St. Paul referendum for Land of 10,000 Loves. However, my research focused on the Tretter Collection, whose founder, Jean Tretter, was an active member of SPCHR and continued to express undiluted hatred for Bryant and Angwin forty years later. Unflattering portrayals of the group may not have made their way to the archive.

132 "Capitol Forum" (undated), Portland Town Council Records, box 2/14, Oregon Historical Society.
} 
against Bryant that referred to her as "that Anita bitch" and suggested gay radicals kidnap her children and hold them for ransom until she returned "back to her kitchen forever." The author promptly shifted blame to the PTC's efforts at obtaining gay rights through legislative means: "Wake up! Strong measures are going to have to be put in operation and soon to shut this hypocrite up for good...There is no other way--short of murder--to halt this bitch. Get with it. I'm sick of her!" ${ }^{133}$ The PTC recorded the date it received the anonymous letter and promptly doomed it to an office file.

If ECHR and VOICE largely refrained from associating themselves with the aggressive claims and threats of outsiders, then they had no problem observing those associations when they involved the other side. "Each side has accused the other of unfair campaign tactics, the Oregonian observed, "including late-night harassing phone calls, bringing in non-Eugene voters and campaign workers, and misinforming the public." ECHR claimed, for instance, that "a group of zealots, many of them from small town outside Eugene," had instigated the referendum, and those outsiders were "inspired by Anita Bryant and by recent progress of gay rights in the state legislature." ${ }^{134}$ Outsiders, including Bryant and the State government were used, then, as a rhetorical tool to scare voters into supporting a particular side's position. ${ }^{135}$ Nonetheless, national comparisons were necessary at some level, especially to give organizers both a means of mobilizing their base and an idea of what they might expect from voters. Candy Hansen, a ECHR spokesperson, made a comparison to the referendums in St. Paul and Wichita with their

\footnotetext{
${ }^{133}$ Anonymous note received by the Portland Town Council dated May 16, 1978, Portland Town Council Records, box 2-12, Oregon Historical Society.

134 "Can We Win a Gay Rights Referendum? Yes! In Eugene, Oregon" flier, Portland Town Council Records, Oregon Historical Society, box 3-5 "Eugene Referendum" folder.

${ }^{135}$ Clay Eals, "Follow Other's Repeals? Eugene to Vote on Gay Rights Law," Oregonian, May 16, 1978, B5.
} 
overwhelming votes for Nixon in the 1972 presidential elections. Hansen suggested that Eugene, where citizens narrowly voted for Democrat George McGovern, might potentially vote for gay rights and keep with a national liberal tradition.

The liberal tradition became a focus of the last newspaper article that the Oregonian dedicated to the fleeting nondiscrimination ordinance in Eugene. In an opinion piece that occupied more space than any other story on the local referendum--on a page free of ads--correspondent Clay Eals questioned whether Eugene's image as a "politically liberal or progressive town" was simply a myth that the referendum revealed to be false. Local and national observers, Eals noted, had anticipated a much closer result than the 2-to-1 repeal, and suggested that many believed Eugene was the only city of the four targeted in 1977 and 1978 that had a remote chance of preserving gay rights legislation in the face of a referendum. ${ }^{136}$ ECHR shared this sentiment in a letter to supporters during the fight: "If there's any place in the country with a consciousness different from Dade County," it wrote, "if there's one place where our side can win—it's Eugene." ${ }^{137}$ Instead, as Eals noted, fifty-five percent of the voters turned out--compared to the forty-two percent state average--to vote it down. But Eals went on to report that voters did not turn out uniformly across the city; instead, suburban voters, who supported the repeal by seventy to eighty percent margins, represented the highest turnout. In precincts that covered University of Oregon, where opposition to the referendum was highest, turnout was as low as twenty-five percent. ${ }^{138}$ The referendum thus gave an early indication of the "two small town Oregons" that were emerging across the state.

\footnotetext{
${ }^{136}$ Clay Eals, "A Myth?” Ibid.

${ }^{137}$ Terry Bean and Jerry Weller, Mailer from Eugene Citizens for Human Rights, Portland Town Council Records, box 3-5, Oregon Historical Society. ${ }^{138}$ Ibid.
} 
The final vote, tallied on May 24, 1978, was 22,898 in favor of the repeal (63 percent) 13,427 against it (37 percent). When their impending loss became clear, ECHR organizers and other anti-repeal forces marched in a candlelight vigil from the Eugene Hotel to the Lane County Courthouse, where the Rev. Doug Hueke told the crowd of 200 "Don't let 'em snuff out your lights." 139 A few days later, Larry Dean, VOICE's director, received a telegram from Anita Bryant with congratulations for his victory, and with a clear indication that she did not have much regard for the secular tone of his campaign. "Let us continue to reach out in godly love to all homosexuals who want deliverance, while opposing at the threshold [of what is not clear] every attempt of the militant homosexuals to represent their lifestyle as 'normal' and to impose it on us and our children." Covering the exchange, the Eugene Register-Guard noted that Rev. Ron Adrian, director of Wichita's Concerned Citizens for Community Standards (the anti-gay organization), followed VOICE's request for "no outsider interference" and expressed surprise at the wide margin of victory in the Pacific Northwest. Adrian stressed that Wichita's campaign, unlike Eugene's, had stressed morality. Edward Rowe, the executive director of SOC, noted that VOICE received no contribution from the national organization, but it did seek advice in a Miami Beach meeting with the organization's leadership. ${ }^{140}$

A Thorn in the Rose City

${ }^{139}$ Don Nelson, "Defeat Leaves Gay Rights Backers Undeterred," Eugene Register-Guard, May 28, 1978, front page.

${ }^{140}$ Associated Press, "Bryant Sends Her Congratulations to Anti-Gay Victors," Eugene Register-Guard, May 24, 1978, 4F. 
Founded in 1974 as an unofficial association of gay and lesbian businesses, the Portland Town Council (PTC) was a principal force in mapping a politicized gay and lesbian movement onto Oregon's complicated landscape. The PTC officially organized in 1975 and soon became one the state's most powerful gay rights advocacy group. It had organized Oregon's first Gay Pride celebrations in downtown Portland's South Park Blocks, and it was the first organization to request gay rights legislation at the state level. Most notably, in 1976 the PTC published A Legislative Guide to Lesbian and Gay Rights, a compendium of legal solutions to lesbian and gay social problems. The Legislative Guide received national acclaim from the likes of the Rev. Troy Perry, founder of the Metropolitan Community Church, Barbara Gittings, a founder of the Daughters of Bilitis (a "homophile" women's organization), and Portland's mayor, Neil Goldschmidt. ${ }^{141}$ With growing political clout, the PTC eagerly received Goldschmidt's support as an assertion of the local lesbian and gay community's political power. Following his 1976 reelection, Goldschmidt became "the unbeatable superstar of Democratic politics...setting the stage for more lofty political pursuits in $1978 .{ }^{142}$ Receiving his support, then, was equivalent to joining him in an upward rise.

When first elected in 1973, Goldschmidt inherited an office with a troubled past. Before a "Portland revolution" in the 1960s, the mayoral office had supported a notorious political machine by unofficially regulating the city's vice districts through graft, bribery,

\footnotetext{
${ }^{141}$ Neil Goldschmidt, Letter to David Copeland dated December 12, 1977, Portland Town Council Records, Oregon Historical Society. box (10-2) "Personalities: 'Goldschmidt-K"' folder; see also "Legislative Guide folder," box (4-3).

${ }^{142}$ Harry Willis, "Neil Goldschmidt Waits His Moment." The Eugene Register-Guard, October 23, 1977, front page.
} 
and discriminatory police raids. ${ }^{143}$ The corruption and debauchery of the system was especially evident in the city's Old Town, Chinatown, and Italian South Side, where it contrasted sharply with the social expectations of protestant middle class residents who populated the city's east side across the Willamette River. In a reaction to the rampant political corruption, the latter constituencies elected conservative reformers and thus contributed to the Portland's dual reputations a conservative and slow-paced city on the one hand, and as a corrupt den of thieves on the other. ${ }^{144}$ Melding the laid-back social tolerance of the political establishment with the reformist aims of conservatives, Goldschmidt reinvented his office for modern times and cemented himself as a popular politico with keen media savvy and clear results.

In 1977, with a promising career on the horizon, Goldschmidt received a letter from the PTC office that requested an official proclamation of "Gay Pride Day." Jerry Weller, the PTC office coordinator and the letter's author, gave the mayor an abridged history of the Stonewall Riots, which marked, in his words, a "renaissance" of gay pride in the country. "Gay people as never before are...creating a new gay identity," Weller wrote. "In recognition of our basic human dignity and contributions to society in virtually all professions, Milton Schapp, Governor of Pennsylvania proclaimed a gay pride week for his state. Similar actions have taken place in Seattle, Atlanta, and many other cities across the nation. We ask that you join this growing trend." ${ }^{145}$ Like Ruth Shack, who faced no immediate opposition--and had no reason to anticipate it--when she sponsored

\footnotetext{
${ }^{143}$ Robert C. Donnelly, Dark Rose: Organized Crime and Corruption in Portland (Seattle: University of Washington Press, 2011); Portland Exposé (1957) dir. Howard Schuster.

${ }^{144}$ Carl Abbott, Portland in Three Centuries: The Place and the People (Corvallis, OR: Oregon State University Press, 2011), 139-154; Phil Stanford

145 Jerry Weller, Letter written to Neil Goldschmidt dated May 23, 1977, Portland Town Council Records, Oregon Historical Society,, box (10-2) "Personalities: 'Goldschmidt-K'" folder.
} 
an addendum to the Dade County Code in 1976, Goldschmidt confidently issued an official declaration that seemingly had little bearing on Portland politics or his career.

The call for an official proclamation of "Gay Pride Day" to specifically commemorate the Stonewall riots suggested that the "Stonewall Myth," as identified by Elizabeth A. Armstrong and Suzanna M. Crage, had rapidly emerged across the country. In less than a decade, Stonewall had become a powerful rhetorical tool used by gay and lesbian activists to legitimize the recent rise of gay and lesbian organizing in cities where same-sex relationships had been largely confined to vice districts and rendered antithetical to a "normal" life in places like Portland's east side. ${ }^{146}$ Having occurred only eight years before Weller's request, the Stonewall Riots were already cast as an unprecedented historical marker that could be used to place local calls for political support in a national and historical context. In this case, that call requested political legitimacy, but it also ensured that Stonewall would remain viable and remembered through "Gay Pride" as a commemorative vehicle. If only symbolic, a mayoral declaration of "Gay Pride Day" was an official recognition of late June as a perennial reference point in queer time that needed to be honored, even if the honor was bestowed by a city that was far removed from the riots' Greenwich Village setting and had, until recently, supported the very conditions of oppressive political corruption--namely, police raids--that resulted in Stonewall to begin with. ${ }^{147}$

\footnotetext{
${ }^{146}$ For information on queer life in the vice districts, see: Peter Boag, Sam Sex Affairs: Constructing and Controlling Homosexuality in the Pacific Northwest (Berkeley, University of California Press, 2003); David Grant Kohl, A Curious and Peculiar People: A History of the Metropolitan Community Church of Portland, Oregon and the Sexual Minority Communities of Northwest Oregon (Portland, OR: Spirit Press, 2006).

${ }^{147}$ The riots erupted after police raided Stonewall in accordance with an agreement reach between "Fat Tony," the bar's mafioso owner, and the New York Police Department. See: David Carter: Stonewall.
} 
Weller's reference to the proclamation of Pennsylvania Governor Milton Schapp also suggested the growing influence of a transnational gay and lesbian activist network. In the spring of 1975, Schapp supported a collaborative effort between state agencies and private groups that sought to end discrimination on the basis of sexual preference in his state. The collaboration became the "Pennsylvania Council for Sexual Minorities" and recommended that Schapp issue a ban on discrimination in state employment — the first ban of its kind in the country, though it carried little weight—and prompted him to issue the first state proclamation of Gay Pride week. ${ }^{148}$ Assigned with identifying the problems that lesbian and gay Pennsylvanians faced in employment, housing, and other areas, the Council for Sexual Minorities wrote an influential 1975 report that inspired Oregon Governor Robert Straub to form his own Task Force on Sexual Preference, a twelvemember assembly of representatives with legal, medical, educational, religious, labor, governmental, parental, and minority concerns. ${ }^{149}$ In its concluding report, the Task Force recommended the statewide introduction of nondiscrimination protections; especially in the context of the referendum on SB 100, the recommendation was interpreted as yet another state intrusion on local sovereignty. ${ }^{150}$

Unlike Governor Straub, who gave the sexual minority task force an unprecedented political voice (that was still rather small and largely unheeded), Neil Goldschmidt likely did not give the "Gay Pride Day" proclamation much thought. He vaguely instructed citizens "to acknowledge that advancing the cause of freedom for any

\footnotetext{
${ }^{148}$ See: "Pennsylvania Task Force," box 7/2, and “Segal, Mark (GAA Pennsylvania), 1975," box 7/17, Portland Town Council Records, coll.256, Oregon Historical Society.

${ }^{149}$ See: "Oregon Task Force on Sexual Preference, 1975-1977," boxes 6/5 and 6/6, Portland Town Council Records, coll.256, Oregon Historical Society

${ }^{150}$ Governor's Task Force on Sexual Preference, Final Report of the Governor's Task Force on Sexual Preference. (Eugene, OR: Office of the Governor, 1978).
} 
individual or group advances that cause for all of us" in a one-page document that only represented a goodwill gesture. Like all mayoral proclamations, it carried no legal implications. One local newspaper noted that Goldschmidt issued proclamation "by the dozens" each year for such events as the local American Legion's "Poppy Month," a "Youth Temperance Education Day," and a "Navy Mother's Day."151 The declaration of Gay Pride Day" was nonetheless received as an official approval of the local lesbian and gay community in Portland. Issued a few weeks after the Dade County referendum, Goldschmidt's proclamation reflected the limited effect of Save Our Children's immediate aftermath, in which a "post-Anita" national atmosphere had not yet reached the Pacific Northwest. He, like anyone else who read a newspaper, owned a radio, or had access to televised newscasts, was aware of the fight in Miami, but there was little indication that Anita Bryant's campaign would inspire similar anti-gay countermovements outside of Florida. ${ }^{152}$

That indication was illusory. Five days after the proclamation of Gay Pride Day, the Oregon Journal published an open letter to Goldschmidt, penned by a group of angry Portlanders that castigated the Mayor for his support. "When elected officials proclaim special days honoring meritorious and heroic actions or even championship basketball teams," the authors wrote anonymously, "it is to be applauded. When, however, they use their position to honor a practice which is repulsive to many and morally degrading to the community, it is a misuse of their office." ${ }^{153}$ In July 1977, exactly one month after "Gay Pride Day," the authors organized Citizens United to Protect Our Children (CUPOC), and

151 "Silence a Rarity," Oregon Journal, October 24, 1977, front page.

${ }^{152}$ St. Albin-Greene, front page.

${ }^{153}$ Citizens United to Protect Our Children, "An Open Letter to Mayor Neil Goldschmidt," Oregon Journal, June 30, 1977. 
formally began a campaign to recall Goldschmidt from the mayor's office. CUPOC's name, of course, directly referenced Anita Bryant's "Save Our Children," and the group claimed an army of two hundred volunteers who began a door-to-door campaign to obtain 25,120 valid signatures required in a six week period to initiate a special referendum. ${ }^{154}$ In August, Goldschmidt wrote the Portland Town Council with thanks for its support during the recall campaign. He reiterated his support for employment nondiscrimination despite its unpopularity: "I feel such a reminder of this country's Constitutional respect and tolerance for human and individual rights, though it may be unpopular, is sometimes necessary." ${ }^{155}$ Goldschmidt's letter suggested that he was once again prepared to take criticism for his support of specific gay and lesbian-friendly platforms. Unlike the newspapers in Miami, which largely supported the repeal of Dade County's gay rights ordinance, Portlanders overwhelmingly panned the 1977 recall effort: "This is the dark side of Oregon History," Floyd McKay, a local political reporter, said on KGW-TV." The side that wrote into the constitution a ban on blacks living in Oregon.

The side that tried to close all Catholic schools until the U.S. Supreme Court stopped us. The side that sent Japanese Americans to concentration camps." He continued:

If this recall effort had been better organized, this dark side of us would have written another sorry chapter. Neil Goldschmidt would have beaten it, of course. He has been a good and honest mayor. But the campaign would have exposed the depth and heat of prejudice in our community. This was no movement to remove the mayor...let's remove its cloak of religion and respectability and call it what it is... a flat-out get-the-queers campaign. Citizens to Protect our Children indeed. Protect us all from mean spirits and closed minds. ${ }^{156}$

\footnotetext{
154 "Recall Roll Nears 20,000," Oregonian, October 11, 1977, front page; "Goldschmidt Recall Petition Drive Unsuccessful." The Oregon Journal, October 19, 1977.

155 Letter from Neil Goldschmidt to Jerry Weller dated August 30, 1977, Portland Town Council Records, Oregon Historical Society, box 10-2, "Personalities: 'Goldschmidt-K'" folder.
} 
The public seemingly agreed with McKay, as CUPOC did not obtain the 25,000 signatures needed to put the remainder of mayor's second term to a vote. A reporter for the Oregon Journal noted that CUPOC's leader, C.L. McDonald, had missed many opportunities to publicize his campaign against Goldschmidt. McDonald replied: "It would have been unbecoming of us as Christians...to try to inflate homosexuality into the 'political football' it has been in some other areas." Throughout the controversy, Goldschmidt neglected to discuss the recall effort with local journalists; one surmised that the mayor's silence on the question of gay rights might have been the goal of CUPOC all along. ${ }^{157}$ Indeed, as Tina Fetner noted in "Working Anita Bryant," the mobilization of lesbians and gay men was an unintended consequence of the anti-gay movement's repeal efforts; "there is no evidence that anti-gay actors were making any attempt to influence the rhetoric of lesbian and gay actors, except perhaps to silence them altogether." ${ }^{158}$ If silence was the goal of the anti-gay countermovement, they succeeded in Portland the next summer, when Goldschmidt was once again asked to proclaim Gay Pride Day.

In 1978, following the string of voter referendums in St. Paul, Wichita, and--much closer to home--in Eugene, Goldschmidt informed the Portland Town Council that he would be unable to attend the year's pride celebration because he would be out of town. Additionally, the mayor notified the Committee that he would not reissue a Gay Pride Day proclamation for 1978. "My reasoning for this decision comes...," he wrote, "from my strong belief that the best interests of the gay community lie not in attempting to force

\footnotetext{
156 Transcript, "McKay Comment," 10/18/1977, Portland Town Council Records, box 2-1, Oregon Historical Society.

157 "Goldschmidt Recall Petition Drive Unsuccessful." The Oregon Journal, October 19, 1977.

158 Tina Fetner, "Working Anita Bryant," 415.
} 
the process of acceptance and accommodations through ordinances, executive orders or official proclamations, but rather to develop a broader constituency of support...from the business, education, and leadership of the community-at-large." He continued:

I say this especially in light of events that have taken place in other municipalities, where [ordinances] caused an unfavorable backlash by scare campaigns that ultimately leave the gay community with less acceptance, less calm consideration of the facts, and more fear. While there almost surely will come a time again where the issues must be forced to a point of decision, in my judgment, that time is not now." 159

If the anti-gay referendum in Miami and CUPOC's attempt at a mayoral recall had no influence on Goldschmidt's public support for the gay and lesbian community, then the 1978 referendums clearly influenced his subsequent silence and refusal.

Goldschmidt's behavior suggested that, by 1978 , the anti-gay countermovement posed credible threats to local politicians who had supported lesbian and gay platforms. But even that support was tepid and fragile; throughout the gay pride scandal of 1977, Neil Goldschmidt did not publicly communicate with the media in regards to CUPOC and only corresponded with the PTC in secret. He eventually caved—-knowingly or not— to CUPOC's demands by refusing to sign a 1978 pride proclamation, refusing to explain why, and thus refusing to address gay and lesbian topics whatsoever. The Portland Town Council largely accepted this silence, and neglected to use the same aggression that Eugene Citizens for Human Rights had directed at the anti-gay countermovement two months earlier. In a reversal of the claims made by Lane County residents that Portland life would invade their city, Portland's queer politics were influenced by the fight in Eugene.

\footnotetext{
${ }^{159}$ Neil Goldschmidt, letter to Jamie Bevson dated June 1978, Portland Town Council Records, Oregon Historical Society, box (10-2) "Personalities: 'Goldschmidt-K'" folder.
} 


\section{Chapter 4: Memories behind the Curtain Analysis and Conclusion}

On March 20, 1978, the Oregonian carried a short AP story from San Francisco, where the City Council had recently passed an employment nondiscrimination amendment by a 10-1 vote. The council followed forty other cities--including the four targeted by Anita Bryant--in extending nondiscrimination to the gay and lesbian population. Not without its own share of controversy, their vote carried a dark indication of problems to come: "There are lots of people who believe strongly that this legislation is wrong and they have very valid feelings," said Councilmember Dan White, the lone dissenter. ${ }^{160}$ Eight months later, after White had resigned from office due to personal problems and subsequently pleaded to have his position reinstated, he entered City Hall through a first-floor window and fatally shot Mayor George Moscone and Supervisor Harvey Milk. Councilmember Dianne Feinstein, who had predicted "some problems

\footnotetext{
${ }^{160}$ Associate Press, "SF Approve Gay Law," Oregonian, March 22, 1978.
} 
coming down the pike" as a result of San Francisco's nondiscrimination ordinance in March, was the first person to discover Milk's body. ${ }^{161}$

The death of Harvey Milk gave a memorable, tangible, and cohesive finale to the narrative of gay life in the 1970s, while the story of Anita Bryant and the four "target cities" only confirmed the decade as a period best known by its lies and failures. After Milk's murder, tens of thousands expressed a collective outrage in an impromptu candlelight vigil that marched from the Castro to San Francisco City Hall. Their vigil represented, albeit in a completely different context and on an exponentially larger scale, the kind of solidarity that Eugene Citizens for Human Rights expressed in their twohundred-strong vigil in May 1978. The San Francisco march also expressed the collective outrage that Gay Pride had annually remembered since the Stonewall Riots in $1969 .{ }^{162}$ But unlike the physical disorganization of gay pride marches, the campy and raucous protests that swirled around Anita Bryant, or the small numbers of the march in Eugene, the silent vigil represented a new kind of queer organizing that belied the complication of its context.

It commenced in the Castro, a district where gay newcomers--including Milk himself--had priced older residents out of the neighborhood, thereby removing much of its local distinctiveness. ${ }^{163}$ Once a working-class area with a diverse population, it changed when an influx of white gay men--many dressed in the popular "Castro clone" style--renovated the housing stock and instigated a hyperbolic rise in property values.

\footnotetext{
${ }^{161}$ Feinstein referred specifically to problems in terms of housing, but nonetheless hinted at other unknown problems. Oregonian, ibid; James Richardson, Willie Brown: A Biography (Berkeley: University of California Press, 1996), 253.

${ }^{162}$ Stephen M. Engel, The Unfinished Revolution: Social Movement Theory and the Gay and Lesbian Movement (Cambridge, UK: Cambridge University Press, 2001), 132.

${ }^{163}$ Randy Shilts, “Castro: Mecca or Ghetto?” Advocate, Issue 209, February 9, 1977, 20.
} 
Milk openly dismissed departing old-timers as "people [who] never did anything for the neighborhood," and added, "We're the best thing to ever happen to this place." ${ }^{164}$ The vigil thus marched for a man who had few ties to San Francisco's political establishment or its longtime residents, and consequently represented the new possibilities of gay politics in heavily concentrated "gay ghettos." 165 When it ended at San Francisco City Hall, a symbol of government that mimicked the classical architecture of state capitols, Congress, and the White House, the vigil further distanced Harvey Milk from a localized sense of place and pushed his memory into a national narrative in which the idiosyncratic, strange, and local fade into "triumphalist histories" that, as historian William L. Lang has noted, have "emphasized national symbols and storylines to the detriment of regional and local identities." ${ }^{166}$

Anita Bryant has shared a related variation--an inverse, perhaps--of Milk’s fate. After vanishing from the national spotlight in 1978, her celebrity reemerged briefly in May 1980, when she and Bob Green filed for divorce. The media's reception of the news was brief, presented as another hypocrisy in the closing chapter of a period that many seemed eager to forget. ${ }^{167}$ But like disco music, vinyl records, and other relics from the 1970s, Bryant has experienced a strange historical revival. To some anti-gay leaders, perhaps, she remains a hero who kept faith in a world that turned against her. In an ironic twist, her return comes from within the queer community, where her name continues to

\footnotetext{
${ }^{164}$ Shilts, "Castro," ibid.

165 John D’Emilio, "Gay Politics and Community in San Francisco Since World War II," Psychological Perspectives on Lesbian and Gay Male Experiences, ed. Linda D. Garnets and Douglas Charles. Kimmel (New York: Columbia University Press, 1993), 72.

${ }^{166}$ William L. Lang, "Beyond Place: A Forum," Oregon Historical Quarterly, vol. 103, no. 4, 416.

${ }^{167}$ Miami News Service, "Family Crusader Anita Bryant Files for Divorce," Miami News, May 23, 1980, $4 \mathrm{~A}$.
} 
play an unwitting, villainous role in the blatant contradictions, quick superfluities, and painful depths of the early gay rights movement. Most notably, long after she had disappeared in a self-imposed exile, Bryant has reemerged in the movie Milk (2008). As I noted in the introduction, her brief cameos pepper the fictitious portrayal of Milk's rise to political power in San Francisco. Like many villains--or, perhaps, like her role in television commercials - the film reduced her into a caricature used to push an idea; she has thus become an historical myth.

But Bryant's legacy, like the legacy of the 1970s, is much more complex. In this paper, I have detailed two nuances in the broader idea of Jack Halberstam's "metronormativity" that suggests the term can be understood as a positional relationship in which one understanding of community imposes, intentionally or not, its reality onto the understandings others. Metronormativity can be understood, then, as the absence of a localized consideration for a farm, village, town, city, metropolis, etc. on its own terms and in the context of a specific time period--it is the failure of one time and place to account for another. For Brandon Teena in the early 1990s, the imposition formed under the pressure of a strict divide between "urban" and "rural," in which Teena defined his home in rural Nebraska as authentic and preferable--his own definition of "rural"--and decidedly unlike the falsehood and discomfort of Lincoln, Nebraska--his understanding of "urban"--in defiance of queer expectations that he leave his rural home for the purported promises and freedoms of larger cities. Reflecting this perspective, Halberstam convincingly portrayed media coverage of Teena's death as evidence of a cosmopolitan imaginary that imposes its comprehension of urban livability onto Teena, thereby 
blaming him for his decision to live where he wanted to, instead of where other queers expected him to live.

The nuances of Halberstam's idea take shape when metronormativity is taken out of this context and placed in another. In Miami in the late 1970s, metronormativity formed as a messy and permeable matrix that broadly connected the explosive battle between gay rights forces and anti-gay ones. More specifically, it cast locals against outsiders in ways that crossed the divide between the two purported opposites. Though she lived in Miami and was the smiling face of one of its principle economies, Anita Bryant represented an ideal of wholesome local motherhood on a national level in her television commercials and, after the passage of gay nondiscrimination protections in late 1977, through her work as the spokesperson for the Save Our Children Campaign. She was also a complicated personification of the contradictory relationship between urbanity and rural life: she lived in a secluded mansion in one of the country's fastest-growing cities with money she earned by portraying a mother wandering around in rural orange groves.

On the gay rights side, Bob Kunst and Jack Campbell represented yet another complex interaction between urbanity and non-urbanity, or the national network against the local city. As the owner of the world's largest gay enterprise — beating gay patronage of the Metropolitan Community Church--Jack Campbell led the local fight for gay rights in a city where he had only lived for a handful of years. Like other residents of Coconut Grove, he used mass media, including Newsweek and the Advocate, to present gay life as urban, sophisticated, uniform, and fabulously wealthy. It is no surprise, then, that the activities of Bob Kunst and his more localized interpretation of universal human 
bisexuality had little resonance with the leaders of the DCC, or that the DCC ostracized Kunst from the local fight for gay rights. Further, the DCC's inability to interact with Miamians of color, local lesbians, or local Jewish communities--let alone its inability to find examples of locals who actually lost their homes or employment as a result of an absence of nondiscrimination protections--exemplified their incapacity to view Coconut Grove as a neighborhood in Miami. Instead, they viewed Coconut Grove as a gay colony--akin to Greenwich Village or the Castro--that was composed of people from all cities and thus, from no city.

The metronormativity in Miami can thus be understood as one unlike the metronormativity in Brandon Teena's life, as it did not rely on official or ideological boundaries. Instead, it pervaded understandings of gay/anti-gay, urban/rural, large/small city and belied any discreteness between those; it was rooted in a dichotomy that revealed itself to be a complete falsehood. In the Willamette Valley in 1978, metronormativity can be understood as an inverse of the relationship between the larger and the smaller; instead of a large city imposing its perspective and influence on a smaller community, events in the smaller community impacted the gay rights in a larger and purportedly more imperatively urban location. In Eugene, the referendum battle between gay and anti-gay factions became purposefully localized to the community that would vote; unlike Miami, St. Paul, and Wichita, its organizers did not seek outside sources--even if it received money and attention anyway.

Instead, Eugene residents on both sides of the fight used the specter of outside influence as a weapon against their opponent. Gay rights activists used Anita Bryant to label their foes as religious zealots, whereas anti-gay organizers presented San Francisco 
as a large army that threatened to spill over the Calapooya Mountains into the unwitting town below. If metronormativity was an unexplored liability in the fight for gay rights in Miami, it became a rhetorical tool for Oregonians a year later. This paper expands the idea of metronormativity beyond a linear relationship between the closeted "rural" and the visible "urban" or, perhaps, between the image of the Kansas farm and the Emerald City. Beyond this positionality, and even beyond queer theory, metronormativity becomes a helpful frame for analyzing the complexities that surround an imposition of place-based ideas against others. Taken out of the context of Teena's life, metronormativity offers a counterpoint to queer localization, a close-up of the network of geography and temporality that situates the struggles between different perspectives on place, time, and the myriad memories that the two produce. 
Bibliography

Abbott, Carl. Portland in Three Centuries: The Place and the People. Corvallis, OR: Oregon State University Press, 2011.

Anita Bryant Collection. Jean-Nickolaus Tretter Collection in Gay, Lesbian, Bisexual, and Transgender Studies, University of Minnesota Libraries.

Anita Bryant Ministries, “Anita Bryant Biography.” Accessed February 26, 2013. http://www.anitabmi.org/3.html.

Armstrong, Elizabeth A., and Suzanna M. Crage. "Movements and Memory: The Making of the Stonewall Myth." American Sociological Review 71, no. 5 (2006): 724-751.

Arnold, John. "Metro Must Reconsider Gay Law.” The Miami Herald, March 15, 1977, sec. B.

Associated Press. "It's O.K. to move to Oregon Again." Spokane Spokesman-Review, December 9, 1975, 7.

--- "Gay Rights Law Beaten in Miami." Pittsburgh Post-Gazette, June 8, 1977, front page.

---“Group Ordered to Drop 'Save Our Children' Title.” Palm Beach Post-Times, July 16, 1977, sec. B.

---“Homosexuals Welcome.” St. Petersburg Independent, July 8, 1977, sec. A.

---“Agency Drops Anita Bryant.” Lakeland Ledger, July 7, 1977, sec. A. 
---“Anita Favors U.S. Law Outlawing Homosexuality.” Miami News, November 3, 1977, sec. A.

---“Threats Won't Stop Anita Bryant.” Toledo Blade, November 3, 1977, sec. A.

---“Anita Bryant Leaves New York Because of Threats to Her Life." Ottawa Citizen, November 3, 1977, sec. A.

---“Bryant Sends Her Congratulations to Anti-Gay Victors," Eugene Register-Guard, May 24, 1978, sec. F.

---"Bryant Tearful at Wichita Rally," Lawrence Journal-World, December 7, 1977, page 7.

---“SF Approve Gay Law,” Oregonian, March 22, 1978.

Boag, Peter. Sam Sex Affairs: Constructing and Controlling Homosexuality in the Pacific Northwest. Berkeley, University of California Press, 2003.

Boone, Mary. Uniquely Oregon. Chicago: Heinemann Library, 2004.

Brader, David S. "Here Comes High Tech: Oregon's Economic Climate Rapidly Changing." Bend Bulletin, March 3, 1985, sec. B.

Braukman, Stacy. Communists and Perverts under the Palms: The Johns Committee in Florida (Gainesville, FL: University Press of Florida, 2012.

Carter, David. Stonewall: The Riots that Sparked the Gay Revolution. New York: St. Martin's Press, 2004.

Capó, Jr., Julio. "Reinterpreting the Anita Bryant Story: How Massive Resistance Politicized the Gay Rights Movement in the United States." Making Waves: The Journal for Women's Studies at Florida State University, no. 7 (2009) 1-5.

Chasin, Alexandria. Selling Out: The Gay and Lesbian Movement Goes to Market. New York: St. Martin's Press, 2000.

Chauncey, George. Gay New York: Gender, Urban Culture, and the Makings of the Gay Male World, 1890-1940. New York: Basic Books, 1997.

Citizens United to Protect Our Children. "An Open Letter to Mayor Neil Goldschmidt." Oregon Journal, June 30, 1977, section B.

Clendinen, Dudley, and Adam Nagourney. Out for Good: The Struggle to Build a Gay Rights Movement in America. New York: Simon \& Schuster, 1999.

Collins, Huntly. "City Bans Homosexual Bias from Employment Policies." Oregonian, December 19, 1974, front page.

---"McCready Puts Political Courage on Line." Oregonian, December 24, 1974, sec. A. 
Curtin, Jane. "Saturday Night Live," dir. Lorne Michaels. New York: NBC Television, September 24, 1977.

Dearborn, H. and J. Goicochea Duclos. "1930 and 1970 Population." In Willamette River Basin Planning Atlas: Trajectories of Environmental and Ecological Change edited by David Hulse, Stan Gregory, and Joan Baker, 54-55. Corvallis, OR: Oregon State University Press, 2002.

De Groot, Gerard. The Seventies Unplugged: A Kaleidoscopic Look at a Violent Decade. London: MacMillian, 2010.

D’Emilio, John. "Gay Politics and Community in San Francisco since World War II.” In Psychological Perspectives on Lesbian and Gay Male Experiences, edited by Linda D. Garnets and Douglas Charles Kimmel, 456-473. New York: Columbia University Press, 1993.

Detamore, Mathias J. "Queer Appalachia: Toward Geographies of Possibility." PhD diss., University of Kentucky, 2010.

DeWitt, Jack. Portland Exposé, dir. Howard Schuster. Los Angeles: Lindsley Parsons Picture Corporation, 1957.

Donnelly, Robert C. Dark Rose: Organized Crime and Corruption in Portland. Seattle: University of Washington Press, 2011.

Drake, Susan with Bill Brubaker. "Anita Bryant: A Cooler Crusader," Newsweek 90, no.11, Oct. 3, 1977, feature article.

Duggan, Lisa. "The New Homonormativity: The Sexual Politics of Neoliberalism." In Materializing Democracy: Toward a Revitalized Cultural Politics, edited by Russ Castronovo and Dana D. Nelson 175-194. Durham, NC: Duke University Press, 2002 .

Eals, Clay. "Eugene Groups Gird for Vote on Gay Rights.” Oregonian, May 1, 1978, sec. M.

---“Eugene's Liberal Image: A Myth?” Oregonian, sec. B.

---“Follow Other's Repeals? Eugene to Vote on Gay Rights Law," Oregonian, May 16, 1978 , sec. B.

Engel, Stephen M. The Unfinished Revolution: Social Movement Theory and the Gay and Lesbian Movement. Cambridge: Cambridge University Press, 2001.

Eskridge, William. Gaylaw: Challenging the Apartheid of the Closet. Cambridge, MA: Harvard University Press, 2002. 
Eugene Register-Guard editorial staff. "Vote on Gay Rights?" Eugene Register-Guard, October 28, 1977, sec. A.

Faderman, Lillian and Stuart Timmons. Gay L.A.: A History of Sexual Outlaws, Power Politics, and Lipstick Lesbians. New York: Basic Books, 2006.

Fetner, Tina. How the Religious Right Shaped Lesbians and Gay Activism. Minneapolis: University of Minnesota Press, 2008.

---"Working Anita Bryant: The Impact of Christian Anti-Gay Activism on Lesbian and Gay Movement Claims." Social Problems 48, no. 3 (2001): 411-428.

Fitzgerald, Joan. Emerald Cities: Urban Sustainability and Economic Development. London: Oxford University Press, 2010.

Fountain newspaper collection. Oregon Historical Society, Research Library.

Fuller, Tony and Holly Camp. "Anita Bryant vs. the Homosexuals." Newsweek, June 6, 1977, feature article.

Gieber, Maureen. "Rinse Preferred.” Eugene Register-Guard, October 30, 1964, sec. A.

Goldberg, Morris M. “Gay Rights Debate Quixotic.” Letter to the Miami Herald, March 15,1977 , sec. B.

Good Housekeeping editorial staff. "Results of GH's Eleventh Annual Ten Most Admired Women Poll," Good Housekeeping 190, (1980): 46.

Governor's Task Force on Sexual Preference. Final Report of the Governor's Task Force on Sexual Preference. Eugene, OR: Office of the Governor of Oregon, 1978.

Kohl, David G. A Curious and Peculiar People: A History of the Metropolitan Community Church of Portland, Oregon and the Sexual Minority Communities of Northwest Oregon. Portland, OR: Spirit Press, 2006.

Hacker, David W. “Anita Bryant Tells Why She's Against Gay Rights.” National Observer, March 12, 1977, feature article.

Halberstam, Judith "Jack." In A Queer Time and Place: Transgender Bodies, Subcultural Lives. New York: New York University Press, 2005.

Hanhardt, Christina B. "Butterflies, Whistles, and Fists: Gay Safe Street Patrols and the New Gay Ghetto, 1976 - 1981.” Radical History Review: Queer Futures 100 (Winter 2008): 70. 
Herring, Scott. "Southern Backwardness: Metronormativity and Regional Visual Culture." American Studies 48 no. 2 (Summer 2007): 37-48.

--- "Out of the Closets, Into the Woods: RFD, Country Women, and the Post-Stonewall Emergence of Queer Anti-Urbanism." American Quarterly 59, no. 2 (2007): 341372.

Hibbard, Michael. "Land Use Planning and the Future of Oregon's Timber Towns." In Planning the Oregon Way: A Twenty-Year Evaluation, edited by Carl Abbott, Deborah Howe, and Sy Adler, 189-201. Corvallis, OR: Oregon State University Press, 1994.

Holmberg, David. "Repeal Urged to Kill Election on Gay Rights." Miami News, March 23, 1977, front page.

---“Gay Rights: The Emotions, At Least, Are in the Open Now," Miami News, March 23, 1977, front page.

Jagose, Annamarie. Queer Theory: An Introduction. New York: New York University Press, 1996.

Jernigan, David. "Why Gay Leaders Don't Last: The First Ten Years After Stonewall," Out/Look (Summer 1988): 33-49.

Kaiser, Charles. The Gay Metropolis: The Landmark History of Gay Life in America. New York: Grove Press, 2007.

Kazyak, Emily A. "The Space and Place of Sexuality: How Rural Lesbians and Gays Narrate Identity.” PhD Diss., University of Michigan, 2010.

Kelley, Ken. "Cruising With Anita." Playboy 25 no. 97, (March 1978), 232-242.

Klingle, Matthew W. Emerald City: An Environmental History of Seattle. New Haven: Yale University Press, 2007.

Kramer, Linda. "Gay Rights Bill Goes Before Eugene Council Monday." Oregonian, October 25, 1977, sec. A.

Kunst, Bob. "Anita Bryant calls Dade County “A National Battleground," Press Release of the Transperience Center, March 21, 1977.

Kunzel, Regina. "Lessons in Being Gay: Queer Encounters in Lesbian and Gay Prison Activism." Radical History Review: Queer Futures 100 (Winter 2008): 11-37.

Lang, William L. "Beyond Place: A Forum.” Oregon Historical Quarterly 103, no. 4 (Winter 2002) 414-51. 
Lichtenstein, Grace. "Life Easier for America's Gays, Despite Anita Bryant Effort." The New York Times, August 21, 1977.

Lucoff, Morton. "Homosexual Groups Urging Anti-Bias Law." Miami News, November 16, 1976, sec. A.

--- "Bias Law on Gays Draws Opposition." The Miami News, January 17, 1977, sec. A.

--- "Wording Mars Repeal Drive of Law on Gays." Miami News, February 2, 1977, sec.

A.

---“Countywide Vote on Gay Rights.” Miami News, March 15, 1977, front page.

McCreery, Patrick. "Save Our Children/Let Us Marry: Gay Activists Appropriate the Rhetoric of Child Protectionism." Radical History Review: Queer Futures 100 (winter 2008): 186-207.

Medler, Jerry and Alvin Mushkatel. "Urban-Rural Class Conflict in Oregon Land Use Planning.” Western Political Quarterly 32 no. 3, (Sep. 19790): 338-349.

Miami News editorial staff. "Repeal Gay Ordinance, "Miami News, March 16, 1977, sec. B.

---“Vote FOR Repeal of Gay Ordinance.” Miami News, June 6, 1977, sec. B.

Miami News Service. "Family Crusader Anita Bryant Files for Divorce." Miami News, May 23, 1980, sec. A.

Miller, Mark and Matt Propert. National Geographic Traveler: Miami and the Keys. Washington, D.C.: National Geographic 2012.

Nelson, Don. "Defeat Leaves Gay Rights Backers Undeterred." Eugene Register-Guard, May 28, 1978, front page.

Nijman, Jan. Miami: Mistress of the Americas. Philadelphia: University of Pennsylvania Press, 2010.

Ortleb, Charles. "Interview: Ethan Geto: A Seasoned New York Politico." Christopher Street, August 1977, 21-22, 27.

Phelps, Timothy. "Gay Issue Splits Colorado Cities." Eugene Register-Guard, October 8, 1995 , sec. A.

Phillips-Fein, Kim. "Decisive Decade: Re-evaluating the Seventies." Dissent 58, no. 1 (Winter 2011): 90.

Pope, Dan. "'We Can Wait. We Should Wait.' Eugene's Nuclear Power Controversy, 19681970." Pacific Historical Review 59 no. 3 (August 1990): 349-373. 
Portland Town Council Records, 1974-1982. Oregon Historical Society, Research Library.

Pred, Elenore G. “A Loss in Eugene.” Advocate, issue 244, June 28, 1978, 15.

Pugh, Tison. Innocence, Heterosexuality, and the Queerness of Children's Literature. New York: Routledge, 2011.

Richardson, James. Willie Brown: A Biography. Berkeley: University of California Press, 1996.

Richmond, HR. "Unique Public Interest Law Group Supports Oregon Land Use Program." Land Use and Zoning Law Digest 31 no. 10, (1979): 435-484.

Robert, Jack. "New Gay Law Causes Flap.” Miami News, February 1, 1977, sec. A.

Rogers, Neil. "Human Rights in Conflict," Miami News, March 18, 1977, sec. A.

Rose, Frank. "Trouble in Paradise." New Times Magazine, April 15, 1977, feature article.

Saint Albin-Greene, Daniel. "Anita Will Find Washington, D.C. is A Capital Place for Gays." The National Observer, June 20, 1977, feature article.

Schiller, Preston L. "Connections within the Western U.S.-Canada Border Region: Toward More Sustainable Transportation Practices." Transboundary Policy Challenges in the Pacific Border Regions of North America, edited by Donald K. Alper, John C Day, and James Loucky, 93-119. Calgary, University of Calgary Press, 2008).

Schoonens, Terry. Letter to the editor, Miami News, March 18, 1977, sec. A.

Scott, Kelly. "Anita Bryant, Concert Brings Clash of Gay, Straight Lifestyles.” St. Petersburg Times, November 9, 1977, sec. B.

Sears, James T. “Bob Basker (1918-2001): Selling the Movement.” In Before Stonewall: Activists for Gay and Lesbian Rights in Historical Context, edited by Vern L. Bullough, 193-201. New York: Harrington Park Press, 2002.

Seldin, Ellen. "Anita Bryant: She Wants to get back to Being a Mommy, Again." Miami Beach Sun-Times, March 6, 1977, front page.

Shilts, Randy. “Castro: Mecca or Ghetto?” Advocate, Issue 209, February 9, 1977, 20. ---The Mayor of Castro Street: The Life and Times of Harvey Milk. New York: St. Martin's Press, 1988. 
Silverman, Victor and Susan Stryker. Screaming Queens: the Riot at Compton's Cafeteria, DVD. San Francisco: Frameline, 2005.

Simmons, Matty. Fat, Drunk, and Stupid: The Inside Story Behind the Making of Animal House. New York: St. Martin's Press, 2012.

Steele, Richard with Holly Camp. "In the Gay Camp." Newsweek, June 6, 1977, feature article.

Stein, Marc. "Theoretical Politics, Local Communities: the Making of U.S. LGBT Historiography." GLQ: A Journal of Lesbian and Gay Studies 11: no. 4 (2005): 605-625.

Stone, Amy L. and Jane Ward. "From 'Black People are not a Homosexual Act' to 'Gay is the New Black': Mapping White Uses of Blackness in Modern Gay Rights Campaigns in the United States." Social Identities 17 no. 5, (September 2011): 605-624.

Stryker, Susan. Transgender History. Berkeley, CA: Seal Books, 2008.

Twin Cities Pride Committee. The People United. The People Strong. Minneapolis, Twin Cities Pride Committee, 1977.

United Press International. “Anita Bryant to Protest Gay Rights Ordinance.” St. Petersburg Times, January 18, 1977, sec. B.

---“Florida Orange Juice 'Gaycott' Picks up California Support,” St. Petersburg Times, April 22, 1977, sec. B.

---“Homosexuals on March for Rights, Against Anita Bryant." Montreal Gazette, June 27, 1977, 41.

--."Anita Bryant Says She is Tired of Being 'Persecuted."' St. Petersburg Times, October 28, 1977, sec. B.

---“Anita Bryant Won't Co-Host Orange Parade," Florence Times-Daily, December 8, 1977, 14.

U.S. Bureau of the Census. "History: Urban and Rural Areas." Accessed February 8, 2013.

http://www.census.gov/history/www/programs/geography/urban_and_rural_areas. html.

Van Cleve, Stewart. Land of 10,000 Loves: A History of Queer Minnesota. (Minneapolis: University of Minnesota Press, 2012.

Van Gelder, Lawrence. "Judy Garland's Funeral Draws Her Colleagues." New York Times, June 28, 1969: http://www.nytimes.com/books/00/04/09/specials/garlandfuneral.html. 
Waitt, Gordon. "Playing Games with Sydney: Marketing Sydney for the 2000 Olympics." Urban Studies, 36 no. 7 (1999): 1055-1077.

Williams, Daniel K. God's Own Party: The Making of the Christian Right. Oxford: Oxford University Press, 2010.

Harry Willis, Harry. "Neil Goldschmidt Waits His Moment." Eugene Register-Guard, October 23, 1977, front page.

Wright, Les. "San Francisco." In Queer Sites: Gay Urban Histories Since 1600, edited by David Higgs, 164-189. New York: Routledge, 1999. 